\title{
A Satellite Observation-based Analysis of Aerosol-cloud-precipitation Interaction during the February 2016 Unseasonal Heatwave Episode over the Indian Region
}

\author{
Sunny Kant ${ }^{1}$, Jagabandhu Panda ${ }^{1 *}$, M.G. Manoj ${ }^{2}$ \\ ${ }^{1}$ Department of Earth and Atmospheric Sciences, National Institute of Technology Rourkela, Odisha-769008, India \\ ${ }^{2}$ Cochin University of Science and Technology, Kerala- 682022, India
}

\begin{abstract}
Aerosol-cloud-precipitation (ACP) interaction during the February 2016 unseasonal heatwave episode over India is analyzed and presented. Moderate Resolution Imaging Spectroradiometer (MODIS) datasets from the Aqua satellite are used to examine the relationship between aerosol and cloud parameters, viz., the aerosol optical depth (AOD), Ångström exponent (AE), cloud fraction, ice and liquid cloud effective radius, cloud optical depth, cloud top temperature, and ice and liquid cloud water path. Furthermore, the Tropical Rainfall Measuring Mission (TRMM) dataset is used to analyze the rainfall during the dissipating phase of the heatwave episode. The prevailing meteorological conditions during the premature, mature, and dissipating phases of the episode are identified by analyzing the near-surface temperature, relative humidity, and vertically integrated moisture flux convergence via $0.25^{\circ}$-resolution ERA-Interim datasets. Back-trajectory analysis is conducted to determine the origin of air masses and transported aerosols. Hot and dry westerly winds dominate during the pre-mature and mature phases, and consequently, significant aerosol transport is observed. The AOD reaches a maximum of 1.6 during the three phases, with the AE being in the range of $0.8-1.7$, indicating the presence of both fineand coarse-mode aerosols. Due to microphysical processes, clouds respond fairly strongly to aerosols in the presence of favorable dynamic and thermodynamic atmospheric conditions. The suppression of precipitation during the pre-mature and mature phases is primarily attributable to weak aerosol-cloud interaction. A major rainfall event in the region comprising northern Odisha, eastern Jharkhand, and most parts of West Bengal, which is situated north of the minimum vertically integrated moisture flux zone, occurs during the dissipating phase. This rainfall event results from the unseasonal transport of moisture from the neighboring Bay of Bengal, the presence of appreciable aerosol loading, and the consequent ACP interaction.
\end{abstract}

Keywords: Aerosol-cloud interaction; Heatwave; Aerosol optical depth (AOD); Rainfall.

\section{INTRODUCTION}

Extreme hot weather is frequent in summer over India. The prevailing warm winds (also known as "loo") during summer typically bring in heatwave conditions over India during March-June. In some years, maximum daytime temperatures exceed $45^{\circ} \mathrm{C}$ for many days over north-western, eastern coastal states, central parts and Indo-Gangetic Plain regions of India (Pattanaik et al., 2016). In summer 2015 and 2016, these regions experienced a severe heatwave condition resulting in loss of several human lives, birds, and animals (Pattanaik et al., 2016; Mishra et al., 2017; Oldenborgh et al., 2018).

The summer heatwave conditions over north-central

\footnotetext{
* Corresponding author.

Tel.: +91-661-2462933

E-mail address: pandaj@nitrkl.ac.in
}

India result from the anomalous subsidence due to the quasi-stationary Rossby wave-train along the African Jet, generated from stretching of upper-level cyclonic vorticity in the west of North Africa induced by blocking over the North Atlantic (Ratnam et al., 2016). In contrast, summertime heatwave over eastern parts of India is due to the anomalous Matsuno-Gill effect that generates cooling in the Pacific and north-westerly anomalies over adjacent landmasses to reduce the land-sea breeze effect (Ratnam et al., 2016). Furthermore, sufficient local forcing on air temperature may have a substantial role in enhancing the intensity of heatwave conditions (Ghatak et al., 2017). Thus, in a changing climate scenario, such episodes may be sensitive to large-scale dynamic effects as well as local or regional ones.

Heatwaves over India are broadly associated with climatic systems or processes including El Niño-Southern Oscillation (ENSO), and also gradients in the sea surface temperatures over north Indian Ocean (Ratnam et al., 2016). Re-curving tropical cyclones over the Bay of Bengal (BOB) 
usually change the direction of winds, inhibit moisture transport to the continental region, and may consequently lead to heatwave conditions over coastal and inland areas. Although heatwave conditions over India are mostly driven by large-scale forcing (Ratnam et al., 2016), regional effects like the ones mentioned cannot be ignored.

Every year, India experiences several heatwaves during the pre-monsoon months (March, April, May). Several studies suggest that urban areas have experienced a significant number of heatwaves in the last two decades (IPCC 2007; Mishra et al., 2015). The most affected regions over the Indian subcontinent are Andhra Pradesh, Telangana, Punjab, Uttar Pradesh, Odisha, Jharkhand, and Bihar (Mishra et al., 2015). Table 1, derived from Ratnam et al. (2016) and originally taken from India Meteorological Department (IMD), shows heatwave episodes occurring over eastern, northern, and central India.

Prevailing heatwaves may increase short-term mortality (Confalonieri et al., 2007). For instance, in 1988, heatwaves caused nearly 1300 deaths (De and Mukhopadhyay, 1998). In 1998 and 2003, about 2042 and 3054 people died (Bhadram et al., 2005), respectively, across India. In 2015, during the pre-monsoon period, heatwaves caused the death of about 2500 people in India (Ratnam et al., 2016). In southern India, including Andhra Pradesh and neighboring areas like Telangana, heatwaves caused more than 1735 and 585 deaths, respectively, in 2015. Other areas in eastern parts of India, including West Bengal, Jharkhand, Bihar, and Odisha, were also influenced by the 2015 pre-monsoon heatwave condition (Bhadram et al., 2005).

Metaxas and Kallos (1980) suggest that the identification of heatwave episodes be based on temperature criteria (i.e., the daily average temperature or the daily maximum temperature must be higher than the average temperature of the corresponding day of past years). The study by Ratnam et al. (2016) suggested supplemental criteria by considering IMD guidelines for identifying heatwave episodes during summer:

(i) A heatwave is not considered until the maximum temperature of the stations reach $40^{\circ} \mathrm{C}$ for plains and $30^{\circ} \mathrm{C}$ for hilly regions.

(ii) When normal maximum temperature of a station $\leq 40^{\circ} \mathrm{C}$, a departure of $+5-6^{\circ} \mathrm{C}$ from normal value is considered a heatwave condition.

(iii) When the normal maximum temperature of a station $>40^{\circ} \mathrm{C}$, a departure of $+4-5^{\circ} \mathrm{C}$ from normal value is considered a heatwave condition.

(iv) When actual maximum temperature $\geq 45^{\circ} \mathrm{C}$, irrespective of normal maximum temperature, a heatwave condition is declared.

(v) For coastal stations, if the maximum temperature $\leq 40^{\circ} \mathrm{C}$, a heatwave may be declared.

If the heatwave episode happens during a non-summer month, it may be classified as an unseasonal one, like the one that occurred during February 2016 over the Indian peninsula. Here, the temperature may exceed 4 to $6^{\circ} \mathrm{C}$ compared with the mean maximum temperature. The present study intends to consider this unseasonal heatwave episode for analyzing potential aerosol-cloud-precipitation (ACP) interaction during the different phases of its occurrence. It may be noted that the heatwave condition would certainly create an unstable environment and may induce transport of air masses from neighboring regions, which may contain aerosols as well as moisture. However, it is not understood clearly how ACP interaction takes place over India during an unseasonal heatwave episode. In view of this, the present study attempts to fill a gap that is quite important as far as ACP interaction over this region is concerned.

The primary microphysical variable that is important when evaluating ACP interaction is aerosol size distribution (Dagan et al., 2015; Kant et al., 2017). The presence of greater numbers of cloud condensation nuclei (CCN) in the atmosphere (Patidar et al., 2012) results in smaller cloud droplet size even with diameter $<1 \mu \mathrm{m}$ (Squires, 1958). Initial size variation of the droplets is the primary factor in determining the effectiveness of condensation processes (Pinsky et al., 2013), and subsequently, it influences the efficiency and beginning of warm rain coalescence and collision processes (Gunn and Phillips, 1957; Warner, 1968; Rosenfeld and Lensky, 1998). The efficiency and magnitude of entrainment also depends upon the amount of aerosol present in convective clouds (Jiang et al., 2006; Xue and Feingold, 2006; Small et al., 2009).

Giant CCN (or GCCN, with diameter $>1 \mu \mathrm{m}$ ) play an

Table 1. List of heatwave episodes over east coast of India, north and central India (Ratnam et al., 2016).

\begin{tabular}{lcc}
\hline & Heat wave events over the east coast of India \\
\hline 29 May-4 Jun 1983 & 01-07 May 1985 & 07-13 Jun 1986 \\
17-23 May 1986 & 07-13 May 1994 & 10-17 May 1996 \\
29 May-07 Jun 1997 & 09-15 May 2002 & 25 May-13 Jun 2003 \\
15-21 May 2007 & 14-20 May 2008 & 26 May-03 Jun 2010 \\
30 May-06 Jun 2012 & & \\
\hline & Heat wave events over north and central India \\
\hline 19-30 May 1984 & 24-30 Jun 1987 & 08-14 May 1988 \\
26-31 May 1988 & 11-21 Jun 1992 & 02-08 May 1993 \\
07-13 Jun 1993 & 29 May-04 Jun 1994 & 30 May-10 Jun 1995 \\
21-28 May 1998 & 07-12 Apr 1999 & 30 Apr-05 May 1999 \\
16-24 Mar 2004 & 15-22 Jun 2005 & 18-27 Jun 2009 \\
18-27 Mar 2010 & 08-20 Apr 2010 & 12-16 May 2010 \\
18-24 May 2013 & & \\
\hline
\end{tabular}


important role in cloud growth and rain formation. Several studies (Houghton, 1938; Johnson, 1982) show that GCCN have an impact on the collision-coalescence process by developing relatively bigger droplets in convective clouds (Lasher-Trapp et al., 2001). Some studies, like Cheng et al. (2009), show that in a relatively polluted environment, GCCN have a bigger impact on the rain rate of convective clouds. This phenomenon can also occur in convective (Yin et al., 2000; Teller and Levin, 2006) and stratiform clouds (Fiengold et al., 1999; Zhang et al., 2006).

Aerosols also have a substantial impact on the microphysical and dynamic structure of stratocumulus and cumulus clouds, and consequently, precipitation formation processes (Segal and Khain, 2006; Pinsky et al., 2008; Khain et al., 2009). Some studies suggest that aerosols suppress rain produced through collision-coalescence process (Albrecht, 1989; Rosenfeld, 1999; Hudson and Mishra, 2007; Niu and Li, 2012; Dagan et al., 2015), whereas some studies suggested concluded enhancement in rain rate (Koren et al., 2012; Niu and Li, 2012; Koren et al., 2014). Some others advocate for the significance of both of these aspects depending upon the prevailing meteorological conditions and geographical location (e.g., Kant et al., 2019a, b). However, some numerical model simulation results show that in a relatively polluted environment, delay in beginning and decrease in the amount of rainfall occurs in convective clouds (Jiang and Feingold, 2006; Altaratz et al., 2008; Xue et al., 2008).

While realizing the complexities involved in ACP interaction discussed above, the present study focuses on analyzing and understanding: (i) relevant meteorological characteristics associated with the February 2016 unseasonal heatwave episode, (ii) prevailing aerosol properties, (iii) associated cloud microphysical properties and (iv) consequent precipitation occurrence and distribution over the study area. The details of the data and methodology adopted for this purpose are briefly discussed in the following section. The results obtained are presented in Section 3, and Section 4 summarizes the findings from this study.

\section{GEOGRAPHICAL LOCATION, DATA AND METHODOLOGY}

The present study is primarily focused on the region of the Indian subcontinent, which was impacted by the unseasonal heatwave during February 2016. Central India covers the states of Madhya Pradesh, Maharashtra, and Chhattisgarh. Summer is usually very hot over this region, with daily high temperatures exceeding $42^{\circ} \mathrm{C}$. During winter, in contrast, the daily high temperature is below $12^{\circ} \mathrm{C}$ (Jain and Kumar, 2012). The western part of India lies near the Thar Desert located in the northwest part of the country. The Arabian Sea is to the west and Vindhya Range is located to the north.

The climate of western India is semi-arid and tropical wet/dry. Daily high temperatures over the western part of India during the summer are above $40^{\circ} \mathrm{C}$ and in winter below $15^{\circ} \mathrm{C}$ (Jain and Kumar, 2012). The eastern part of
India hosts the states of Jharkhand, Bihar, Odisha and West Bengal. Most of the country's population reside near the eastern part of India and Indo-Gangetic Plain (IGP) region. During summer, the high temperatures exceed $38^{\circ} \mathrm{C}$ over this part of the country, whereas winter is very cold (temperature below $10^{\circ} \mathrm{C}$ ).

Southern India consists of states like Karnataka, Tamil Nadu, Andhra Pradesh, Kerala, and Telangana. The southern part of India is encircled by the Arabian Sea in the west, $\mathrm{BOB}$ in the east and the Indian Ocean in the south. Southern India has a non-arid climate. The maximum daily temperature exceeds $45^{\circ} \mathrm{C}$ in summer, whereas winter is colder with minimum temperatures below $18^{\circ} \mathrm{C}$. During February, the maximum daily average temperature exceeds $30^{\circ} \mathrm{C}$, while the minimum daily average value approaches $10^{\circ} \mathrm{C}$ over Madhya Pradesh (Table 2). The variation in daily climatological temperature is found to be maximum $\left(\sim 16.3^{\circ} \mathrm{C}\right)$ over Madhya Pradesh, whereas it is minimum $\left(\sim 10.4^{\circ} \mathrm{C}\right)$ over Tamil Nadu during February. The mean climatological total rainfall falls in the range $0.75-24.3 \mathrm{~mm}$ (Table 2).

The present study uses 17 days (i.e., 12-28 February 2016) of MODIS (Moderate Resolution Imaging Spectroradiometer) level-3 (version 5.1) data from the NASA Aqua satellite for analyzing ACP interaction during the February 2016 unseasonal heatwave episode. The parameters considered for this purpose include aerosol optical depth (AOD), Ångström exponent (AE), cloud fraction (CF), cloud effective radius (CER), cloud optical depth (COD), cloud top temperature (CTT) and cloud water path (CWP). The grid size of MODIS Aqua satellite retrieved datasets is $1^{\circ}$ $\times 1^{\circ}$, and the data are obtained for the $550 \mathrm{~nm}$ wavelength. Since the work carried out uses level-3 products, clouds are already removed from the MODIS aerosol data (Remer et al., 2005).

The uncertainty of MODIS AOD over ocean and land, in the absence of undetected cloud contamination, is $0.03 \pm$ $0.05 \tau$ and $0.05 \pm 0.15 \tau$, respectively (Remer et al., 2005), where $\tau$ is the optical depth. The AE (or " $\alpha$ ") shows spectral characteristic features of aerosols and their size distribution.

The liquid water path (LWP in $\mathrm{g} \mathrm{m}^{-2}$ ) used in this study is primarily a derived product of COD and CER $(\mu)$, indicating the atmospheric column-integrated amount of liquid or ice water (King et al., 1999). Channel frequencies of 10 to $87 \mathrm{GHz}$ and a vertically polarized channel at 22 $\mathrm{GHz}$ (of MODIS) are used to retrieve cloud LWP $\left(\mathrm{g} \mathrm{m}^{-2}\right)$ of non-precipitating and precipitating clouds (Alishouse et al., 1990; Jung et al., 1998). The LWP retrieval uses a unified ocean parameter retrieval algorithm (Wentz and Spencer, 1998), by considering near-surface wind speed, radiative transfer principles, an effective radiative temperature of upwelling radiation, columnar water vapor, rain rate and columnar cloud liquid water content. $\mathrm{CF}$ is the portion or percentage of every pixel that is enclosed by the cloud, and is measured by considering the $41 \times 41 \mathrm{~km}$ area around the pixel (Varnai et al., 2015). The values of CER $(\mu)$ are weighted mean radius of cloud droplets (Bhawar and Devara, 2010). The uncertainty of CER is within 1.0-3.0 $\mu \mathrm{m}$ for 
Table 2. Mean climatological variation of near surface air temperature and rainfall for the month of February (as per India Meteorological Department climatological database).

\begin{tabular}{|c|c|c|c|c|c|}
\hline \multirow[b]{2}{*}{$\begin{array}{l}\text { States (No of stations } \\
\text { considered) }\end{array}$} & \multirow[b]{2}{*}{$\begin{array}{l}\text { Climatology } \\
\text { Years }\end{array}$} & \multicolumn{2}{|c|}{ Mean Temperature $\left({ }^{\circ} \mathrm{C}\right)$} & \multirow{2}{*}{$\begin{array}{l}\text { Difference between } \\
\text { daily maximum and } \\
\text { minimum temperature }\end{array}$} & \multirow[b]{2}{*}{$\begin{array}{l}\text { Mean Total } \\
\text { Rainfall (mm) }\end{array}$} \\
\hline & & $\begin{array}{l}\text { Daily } \\
\text { Maximum }\end{array}$ & $\begin{array}{l}\text { Daily } \\
\text { Minimum }\end{array}$ & & \\
\hline Andhra Pradesh (9) & $1981-2010$ & 32.23 & 20.87 & 11.37 & 6.91 \\
\hline Chhatisgarh (6) & $1971-2000$ & 29.25 & 14.42 & 14.83 & 18 \\
\hline Gujarat (10) & $1981-2010$ & 30.36 & 14.95 & 15.41 & 0.75 \\
\hline Jharkhand (3) & $1981-2010$ & 28.03 & 13.03 & 15.00 & 23.20 \\
\hline Karnataka (16) & $1971-2000$ & 30.48 & 16.53 & 13.95 & 12.41 \\
\hline Madhya Pradesh (7) & $1971-2000$ & 27.29 & 10.96 & 16.33 & 15.03 \\
\hline Maharashtra (7) & $1971-2000$ & 31.41 & 16.24 & 15.17 & 14.63 \\
\hline Odisha (12) & $1971-2000$ & 30.23 & 17.69 & 12.53 & 24.27 \\
\hline Tamil Nadu (12) & $1971-2000$ & 30.63 & 20.27 & 10.36 & 15.68 \\
\hline Telangana (3) & $1981-2010$ & 33.13 & 18.10 & 15.03 & 7.53 \\
\hline West Bengal (6) & $1971-2000$ & 27.73 & 14.10 & 13.63 & 21.43 \\
\hline
\end{tabular}

optically thick clouds (King et al., 1997). The standard deviation of MODIS retrieved CER is within $\pm 0.11 \mu \mathrm{m}$ (Remer et al., 2005). The COD is retrieved by merging of water non-absorbing $(0.65 \mu \mathrm{m}$ for land) and absorbing (1.6, 2.1 and $3.7 \mu \mathrm{m}$ ) bands of MODIS (Platnick et al., 2003). The uncertainty associated with COD may vary within 1021\% (Minnis et al., 2004; Sayer et al., 2016). CTT (K) values are retrieved using the radiance ratio method (Kidder and Vander Harr, 1995), and can be related to the cloud top pressure (Menzel and Strabala, 1997).

Tropospheric Rainfall Measuring Mission (TRMM) 3B42 (version 6) daily precipitation data are used for rainfall analysis. The grid size of the dataset is $0.25^{\circ} \times 0.25^{\circ}$. Furthermore, ERA-Interim global analysis (from European Centre for Medium-Range Weather Forecasts, or ECMWF) data at 12:00 UTC (http://apps.ecmwf.int/datasets) with $0.25^{\circ}$ spatial resolution are considered for analyzing the prevailing meteorological conditions. For this purpose, meteorological variables like near-surface (at $1000 \mathrm{hPa}$ ) temperature, relative humidity $(\mathrm{RH})$ and wind field are considered. The uncertainty in temperature and $\mathrm{RH}$ fields from ERA-Interim is up to $0.05 \mathrm{~K}$ and $0.4 \%$ (Noh et al., 2016). Special attention is given to the air mass transport during an unseasonal heatwave condition by performing back-trajectory analysis using HYSPLIT (HYbrid SingleParticle Lagrangian Integrated Trajectory) model (Draxler and Rolph, 2003) on a daily basis.

The two-sample Student's $t$-test is performed in this study to analyze the probability $(\mathrm{P})$ value of the datasets for MODIS-derived AOD and cloud parameters. The Pvalue signifies that datasets are statistically significant at 95\% confidence level (Kang et al., 2015). Furthermore, the Pearson correlation technique is adopted in the study for determining the correlation coefficients in a similar manner as that of Sarna and Russchenberg (2017).

In order to analyze ACP interaction over the Indian peninsula during the unseasonal heatwave episode, all of the datasets are considered for the period of 12-28 February 2016. For this purpose, the whole period considered in this study is divided into three phases, (a) pre-mature phase (12-16 February 2016), (b) mature phase (17-22 February
2016) and (c) dissipating phase (23-28 February 2016), based on the prevailing meteorological conditions. Accordingly, the corresponding results are analyzed and presented in the following section.

\section{RESULTS AND DISCUSSION}

\section{Prevailing Meteorological Features}

The prevalent meteorological features over the study area are analyzed by considering near-surface air temperature, RH and wind field at $1000 \mathrm{hPa}$. The $1000 \mathrm{hPa}$ mean temperature over the study area at different phases of the unseasonal heatwave scenario superposed with wind field is depicted in Figs. 1(a)-(c), and Fig. 1(d) illustrates the 30-year (1985-2015) climatological mean temperature and wind derived from ERA-Interim data. A comparative analysis is carried out between the climatological mean temperature with that of the different heatwave phases.

The pre-mature phase indicates that the heatwave was developing and the affected area experienced daily high temperatures from 32 to $36^{\circ} \mathrm{C}$ (Fig. 1(a)). The maximum 30 -year mean temperatures are in the range $34-36^{\circ} \mathrm{C}$ (Fig. 1(d)). This is a westward shift from the IMD-observed highest value of the maximum temperature (i.e., $33.13^{\circ} \mathrm{C}$ as mentioned in Table 2) when compared with the spatial distribution of near-surface mean climatological values for February (Fig. 1(d)). In view of this, the pre-mature phase already shows a temperature at par with or above the mean maximum daily value, and a significant area is affected in this stage.

In the mature phase, the heatwave condition had grown and expanded over a relatively large area even up to the northern and eastern part of the Indian peninsula (Fig. 1(b)). Temperatures in some areas over western and southwestern parts of the considered region exceeded $36^{\circ} \mathrm{C}$ (in the range $36-38^{\circ} \mathrm{C}$ ). The area with $>36^{\circ} \mathrm{C}$ gradually increased, occupying most parts of the western and south-western region of the Indian peninsula, which is quite evident in the third phase of the event (Fig. 1(c)). Therefore, a significantly large part of the considered area experienced temperatures of more than $32^{\circ} \mathrm{C}$ and some parts exceeded 

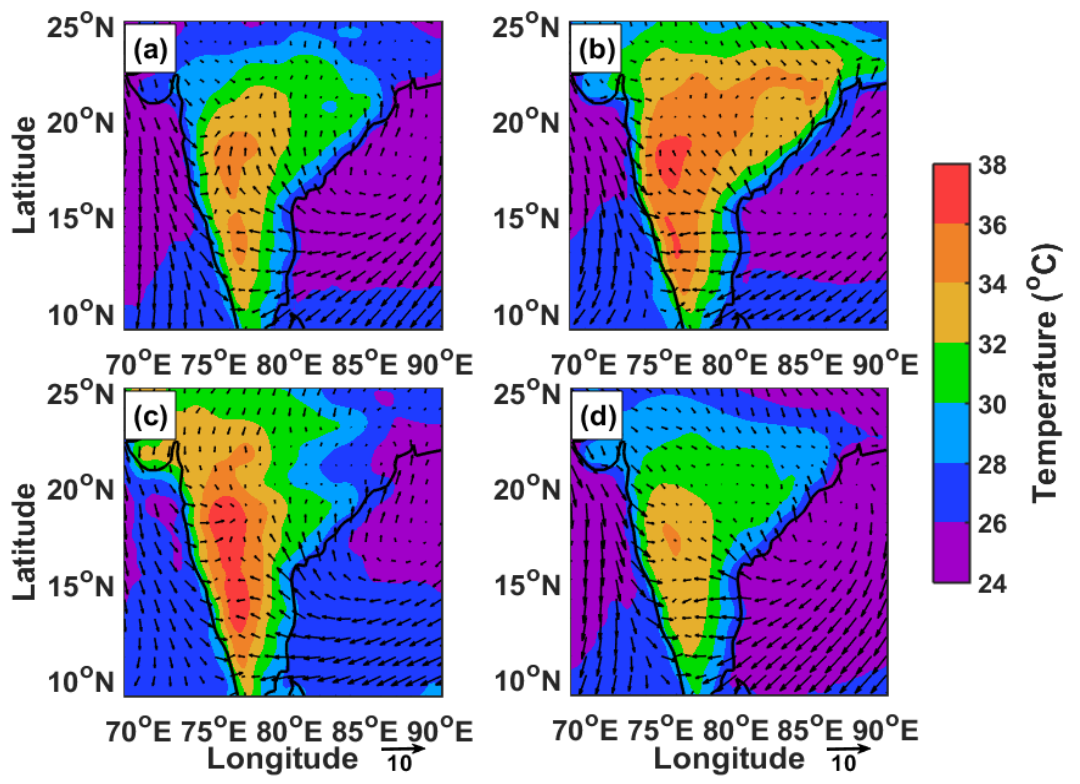

Fig. 1. The spatial distribution of $1000 \mathrm{hPa}$ temperature $\left({ }^{\circ} \mathrm{C}\right.$, shaded contours) and winds ( $\mathrm{m} \mathrm{s}^{-1}$, represented by arrows) during (a) pre-mature phase (12-16 February 2016), (b) mature phase (17-22 February 2016), (c) dissipating phase (23-28 February 2016), and (d) mean temperature (1985-2015 during February) of unseasonal heatwave condition over Indian region. Here, ERA-Interim data of $0.25^{\circ}$ resolution is considered.

$36^{\circ} \mathrm{C}$ (Figs. 1(a)-1(c)), which is quite unusual $\left(4-6^{\circ} \mathrm{C}\right.$ higher) compared to the 30 -year mean.

A predominant westerly wind was found over the study area during the pre-mature and mature phases, whereas during the dissipating phase both easterly and westerly winds were observed near the surface (Figs. 1(a)-1(c)). The flow pattern is similar in the 30-year climatology from ERA-Interim data (Fig. 1(d)). Eastern India is dominated by easterly winds, whereas westerly winds dominate in the western part of the study area (Fig. 1). However, central India is dominated by the prevailing northeasterly and/or northwesterly winds, acting like a convergence region. This is a favorable condition for transport and accumulation of aerosols (Panda et al., 2009; Panda and Sharan, 2012) as well as moisture in the central and eastern parts of the country.

$\mathrm{RH}$ during the pre-mature phase (Fig. 2(a)) is comparatively low (20-40\%) over inland areas, whereas it is relatively high (50-70\%) over coastal regions. The easterly winds advected more moisture from the neighboring ocean to the coastal areas, as indicated by the spatial distribution of RH in different phases (Fig. 2). Hot and dry westerly winds dominate in the mature phase of the unseasonal heatwave episode, increasing the air temperature over western and southern parts of the inland areas up to $\sim 38^{\circ} \mathrm{C}$ (Fig. 1(b)). However, near the coastal area, the mean temperature remains $\leq 30^{\circ} \mathrm{C}$. Eventually, the heatwave condition supports the flow of easterly winds and associated moisture from the neighboring BOB. Consequently, RH increases (maximum up to $80 \%$ ) over coastal areas and a relative decrease $(10-30 \%)$ is seen over the inland areas (Fig. 2) due to convective scavenging. A surge in $\mathrm{RH}$ is seen over coastal West Bengal, including Kolkata, in the dissipating phase of the episode (Fig. 2(c)), thus supporting possible enhanced moist convection.
Convergence of prevalent westerly and easterly winds over the central region may help in the formation of convective clouds through enhanced moisture from the adjoining sea advected to inland regions. It can also increase moisture content over coastal and nearby inland areas. These scenarios may enhance rainfall over some areas of the study region. It is therefore important to understand where the possible occurrence of rainfall takes place. One of the possibilities could be the areas with higher RH (at least $>50 \%$; i.e., in West Bengal and northern parts of Odisha as shown in Fig. 2(c)).

Fig. 3 illustrates the spatial distribution of vertically integrated moisture transport during the three different phases superposed with the near-surface $(1000 \mathrm{hPa})$ wind field. It is computed in a manner similar to Panda et al. (2015) by considering the specific humidity between layers $1000 \mathrm{hPa}$ and $500 \mathrm{hPa}$ and corresponding horizontal wind components. A zone of minimum vertical transport of moisture (1-2 $\left.\mathrm{kg} \mathrm{m}^{-1} \mathrm{~s}^{-1}\right)$ is found in the region extending from south-western India to the north-eastern part, located within longitudes $80-90^{\circ} \mathrm{E}$, irrespective of the phases of the episode (Fig. 3). Increase $\left(>4 \mathrm{~kg} \mathrm{~m}^{-1} \mathrm{~s}^{-1}\right)$ in vertical transport of moisture in other regions is due to the increased wind variability associated with the prevailing convective activity. Increased wind variability can generate a positive feedback cycle between the near-surface winds and convection, with increased evaporation to support enhanced convection (Felton et al., 2013). Such convective transport activity is supported by stronger vertical winds too in the coastal regions, where moisture availability is substantial (Guha et al., 2017). The resulting convective activity supports the enhanced occurrence of rainfall (Fig. 4) in the regions with higher moisture availability or significant vertical moisture transport (Panda et al., 2015). 


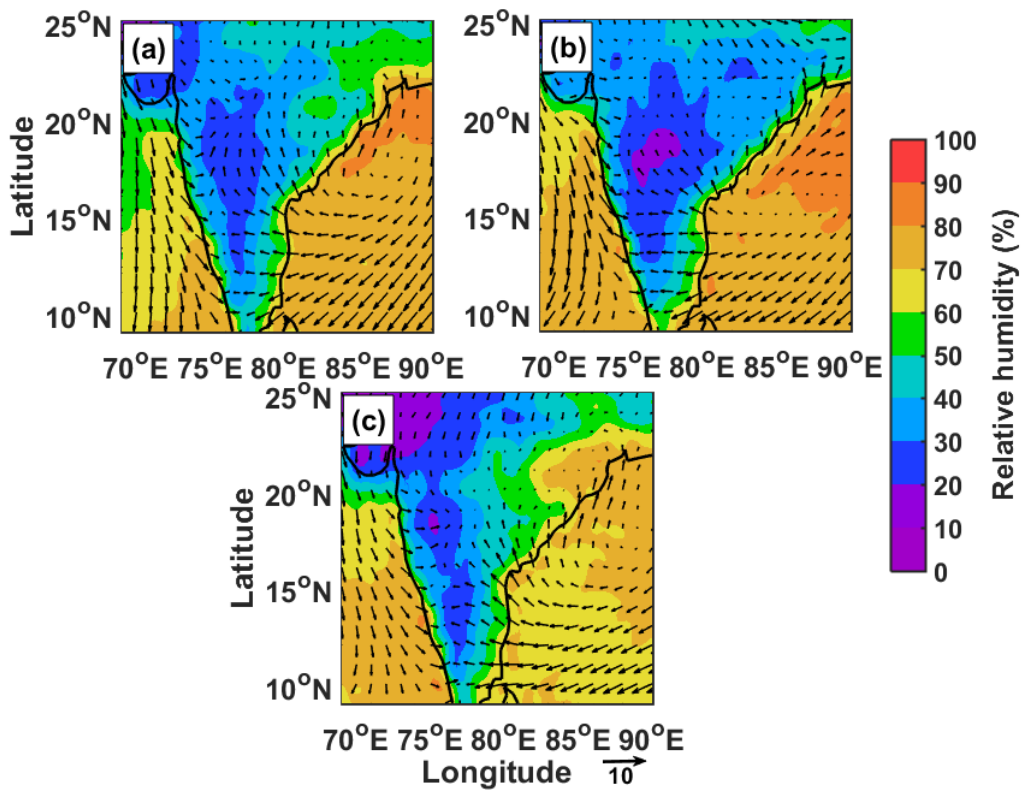

Fig. 2. The spatial distribution of $1000 \mathrm{hPa}$ Relative humidity (\%, shaded contours) and winds ( $\mathrm{m} \mathrm{s}^{-1}$, represented by arrows) during (a) pre-mature phase (12-16 February 2016), (b) mature phase (17-22 February 2016) and (c) dissipating phase (23-28 February 2016) of unseasonal heatwave condition over Indian region. Here, ERA-Interim data of $0.25^{\circ}$ resolution is considered.

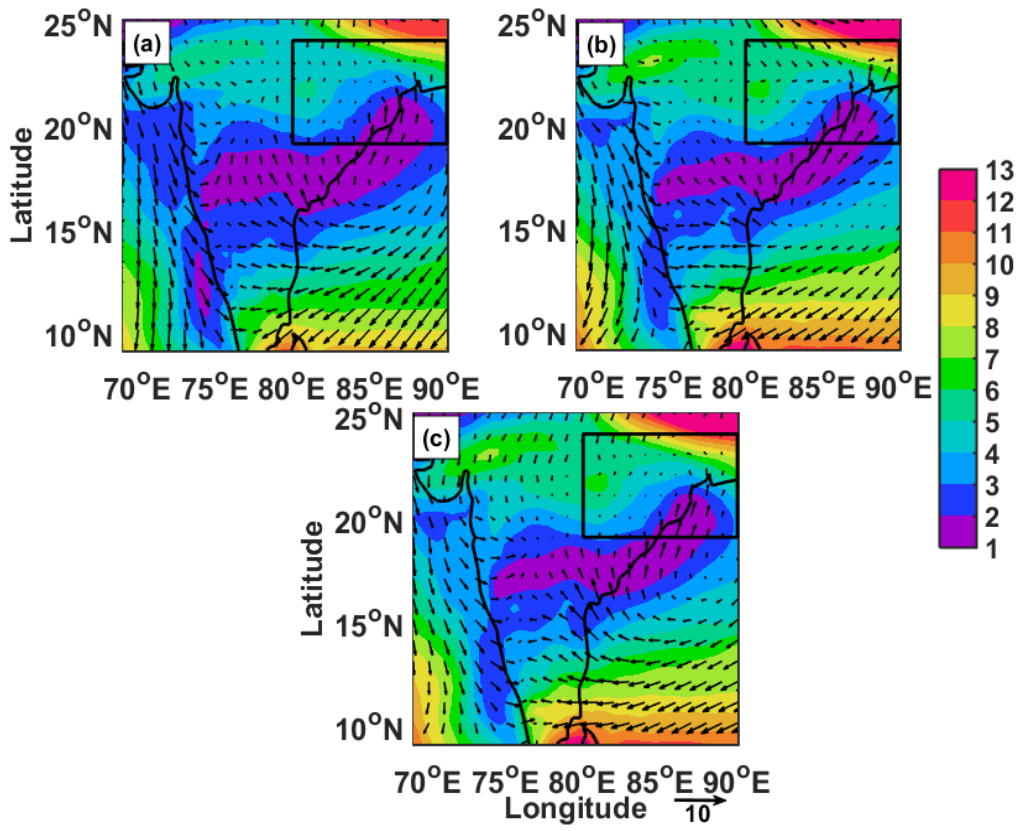

Fig. 3. The spatial distribution of vertically integrated moisture flux convergence $\left(\mathrm{kg} \mathrm{m}^{-1} \mathrm{~s}^{-1}\right)$ superposed by $1000 \mathrm{hPa}$ wind field during (a) pre-mature phase (12-16 February 2016), (b) mature phase (17-22 February 2016) and (c) dissipating phase (23-28 February 2016) of unseasonal heatwave condition over Indian region. ERA-Interim data of $0.25^{\circ}$ resolution is considered for this purpose. Here, the rectangular box is for NMVMF region $\left(19-24^{\circ} \mathrm{N}, 80-90^{\circ} \mathrm{E}\right)$.

Moderate values $\left(2-7 \mathrm{~kg} \mathrm{~m}^{-1} \mathrm{~s}^{-1}\right)$ of vertically integrated moisture flux during the mature phase (Fig. 3(b)) indicates that moist convection and consequent convective activity can also be initiated due to the support from prevailing winds and increased near-surface temperature (Figs. 1-3). Regional warm air advection during the mature phase (Fig. 1(b)) presumably provided enough support for convective activity and subsequent rainfall occurrence mainly during the dissipating phase (Fig. 4(c)). The dominance of stronger easterly winds in the dissipating phase helped moisture transport from the nearby ocean (Figs. 2(c) and 3(c)) and consequently, acted to cool the land surface after the heatwave episode in addition to the cooling effect resulting from rainfall. 


\section{Back Trajectory Analysis}

There was no significant rainfall occurrence over land during the pre-mature and mature phases of the episode (Figs. 4(a)-4(b)). However, the occurrence of appreciable rainfall $\left(0.1-18 \mathrm{~mm} \mathrm{day}^{-1}\right)$ during the dissipating phase took place in the region located north of the minimum vertically integrated moisture flux (NMVMF) (within 19$24^{\circ} \mathrm{N}, 80-90^{\circ} \mathrm{E}$, i.e., mainly over West Bengal, parts of Jharkhand and northern Odisha (Fig. 4(c)). Here, we begin investigation of potential signatures for ACP interaction. Images from MODIS reveal the transport of aerosols along with air masses (in all phases) towards these rainfall areas (Fig. 5). Though this can serve as strong evidence for the presence of aerosols in the designated region, backtrajectory analysis is performed to correlate with substantive potential sources.

Seven days during each phase are considered for the back-trajectory analysis. For this purpose, GDAS (Global Data Assimilation System) data from NOAA is taken, and the trajectories are produced using the HYSPLIT model (Fig. 6). The trajectories attending heights of 500, 1000 and $1500 \mathrm{~m}$ AGL (above ground level) are considered. The air mass trajectories indicate that transportation happens mainly from the areas located in western, southern and eastern parts of the region. During the pre-mature phase, the trajectories for 12 and 15 February (Figs. 6(a)-6(b)) indicate the dominance of western Asian or Arabian air masses compared to those of eastern or southern origin. The 15 February satellite image from MODIS Aqua (Fig. 5(b)) shows transport from the western Asian or Arabian Peninsula to the Indian subcontinent. In the mature phase, trajectories from 17 February indicate transport primarily from the Arabian Peninsula and the Arabian Sea side (Fig. 6(c)) through westerly winds. The likelihood is that corresponding aerosols from these regions would be dust and sea-salts (Gautam et al., 2011).

Trajectories on 27 February show that long-range air mass transportation occurred from the south-eastern side (i.e., BOB) of the Indian subcontinent (Fig. 6(f)) or towards the end of the dissipating phase. This is also seen through MODIS (Fig. 5(d)). The easterly winds help to bring sea salt, and black carbon (BC) and sulfate aerosols produced by biofuel and fossil fuel combustion and biomass burning from south-east Asia (Rajeev et al., 2000; Verma et al., 2008).

\section{Aerosol Characteristics}

The spatial distribution and correlation between mean AOD and AE $(0.412-0.47 \mu \mathrm{m})$ during the pre-mature, mature and dissipating phases of the unseasonal heatwave episode (Fig. 7) are analyzed for understanding primary aerosol characteristics. During the pre-mature phase, AOD is found to be mostly in the range $0.2-1.6$, with $\operatorname{AE}(\alpha)$ values up to 1.7 over the study area (Fig. 7(a)). The AOD is significantly higher over some parts of the eastern region $\left(18-25^{\circ} \mathrm{N}, 80-90^{\circ} \mathrm{E}\right)$. In the pre-mature phase, $\alpha$ values imply that fine-mode aerosols are relatively significant in the atmosphere over the study region.

The aerosol loading in the atmosphere decreases over the study area with a modified spatial distribution of aduring the mature phase (Fig. 7(b)). The range of $\mathrm{AE}$ remains constant. The prevailing hot and dry conditions in the mature phase likely help in the vertical mixing of aerosols due to convective processes. In the dissipating phase, AOD lies mostly in the range $0.2-1.4$ with $\alpha$ being

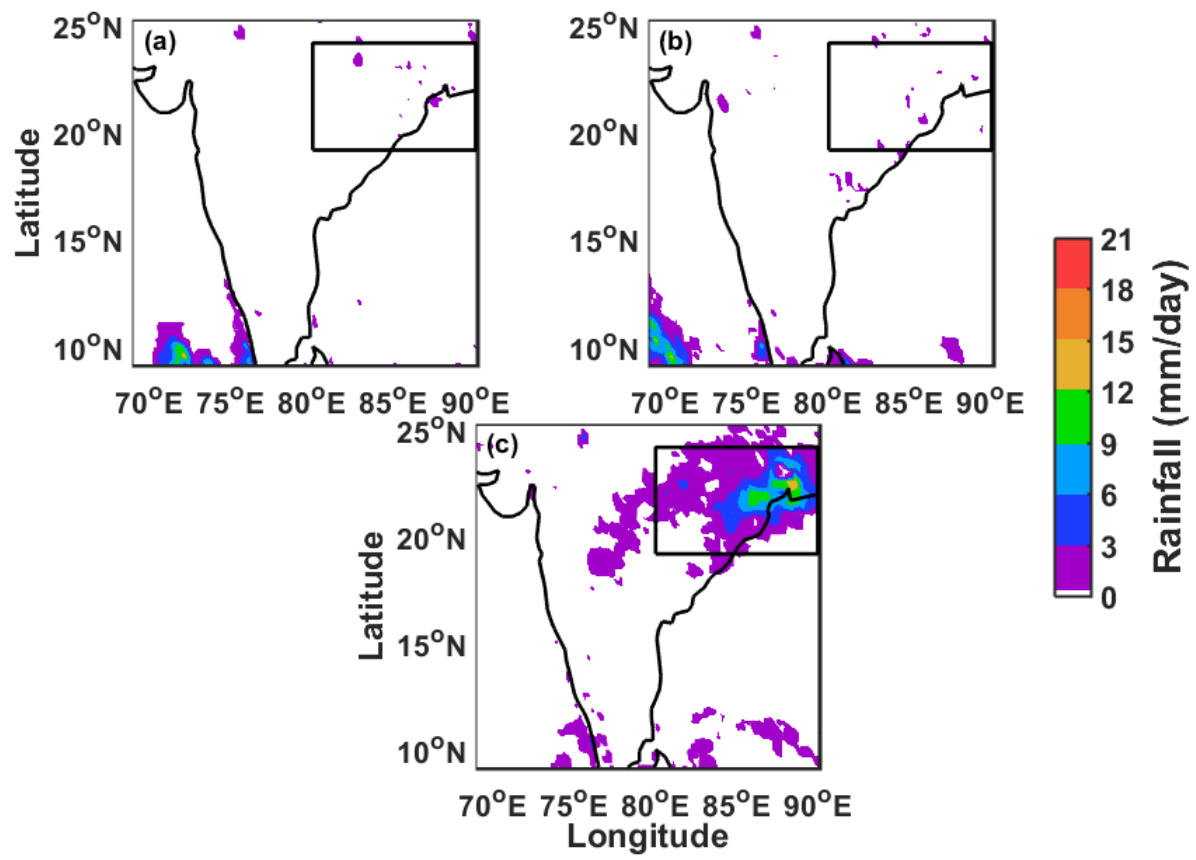

Fig. 4. The spatial distribution of rainfall $\left(\mathrm{mm} \mathrm{day}^{-1}\right)$ during (a) pre-mature phase (12-16 February 2016), (b) mature phase (17-22 February 2016), and (c) dissipating phase (23-28 February 2016) of unseasonal heatwave condition over Indian region. Here, the rectangular box is for NMVMF region $\left(19-24^{\circ} \mathrm{N}, 80-90^{\circ} \mathrm{E}\right)$. TRMM data of $0.25^{\circ}$ resolution is considered for illustrating the rainfall variation. 

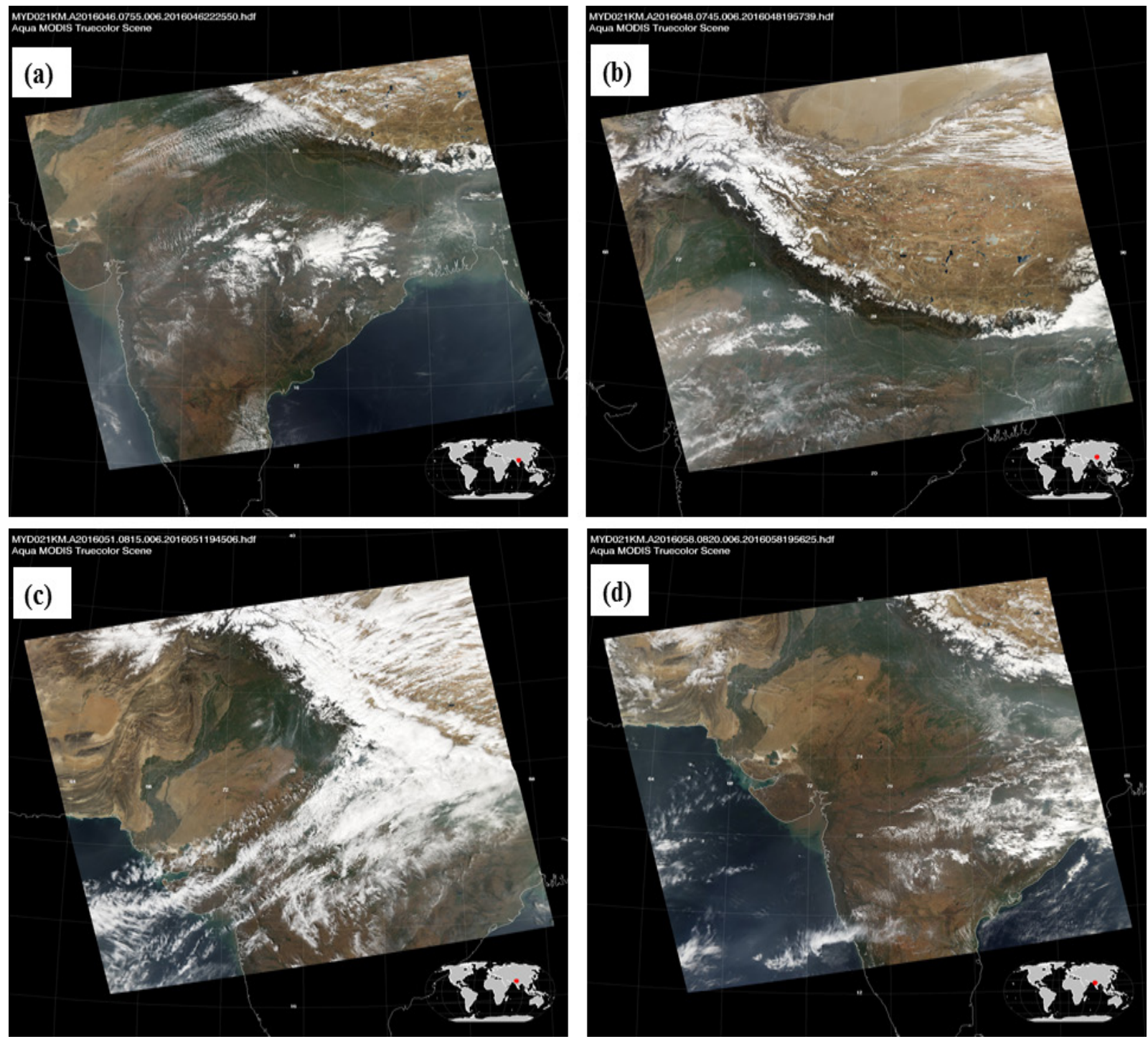

Fig. 5. Transportation of air masses through winds during (a) pre-mature phase (15 February), (b-c) mature phase (17 and 20 February), and (d) dissipating phase (27 February) of unseasonal heatwave condition over Indian region (http://modisat mos.gsfc.nasa.gov/IMAGES/index.html).

0.4-1.7 while the easterly winds are dominant (Fig. 7(c)). The easterly winds help in transporting aerosols from south-eastern parts of the area considered (Figs. 5-7) especially to the NMVMF region (Figs. 3 and 7(c)). Thus, it is presumed that the presence of these enhanced aerosols will perturb background $\mathrm{CCN}$ for cloud in the designated region (Fig. 7) and likely played a significant role in governing the occurrence of appreciable rainfall during the dissipating phase (Fig. 4(c))

The spatial correlation between AOD and AE during all phases of the unseasonal heatwave episode is shown in Figs. 7(d)-7(f)). White color in the figures signifies missing data. Mostly positive correlation is observed over the NMVMF region during the pre-mature phase (Fig. 7(d)). A negative correlation $(-1.0$ to -0.2$)$ is observed during the mature and dissipating phases over the region where rainfall occurred (Figs. 7(e)-7(f)). Asterisks in all phases signify that datasets are statistically significant at the $95 \%$ confidence level (which is valid for other figures too). The value of $\mathrm{AE}$ may also vary with the ratio in changes of fine- and coarse-mode particles in the atmosphere.

\section{Aerosol-cloud-precipitation Interaction}

The previous discussion in Subsections 3.1, 3.2 and 3.3 depicts the presence of aerosols over the NMVMF region (Figs. 3, 5 and 6) where the bulk of observed rainfall occurred (Fig. 4). In order to understand the ACP interaction over the said region, several cloud parameters such as CER $(\mu), \mathrm{COD}, \mathrm{CF}, \mathrm{CTT}(\mathrm{K})$, and CWP $\left(\mathrm{g} \mathrm{m}^{-2}\right)$ are analyzed.

\section{Relationship between $A O D$ and Cloud Fraction}

Cloud fraction $\left(\mathrm{f}_{\mathrm{c}}\right)$ can change with the amount of aerosols present. Several researchers have suggested an increase in $\mathrm{f}_{\mathrm{c}}$ (Loeb and Schuster, 2008; Koren et al., 2010), though others suggest a decrease (Small et al., 2009), with the increase in AOD. In this study, $\mathrm{f}_{\mathrm{c}}$ lies in the range 0.1-0.7 


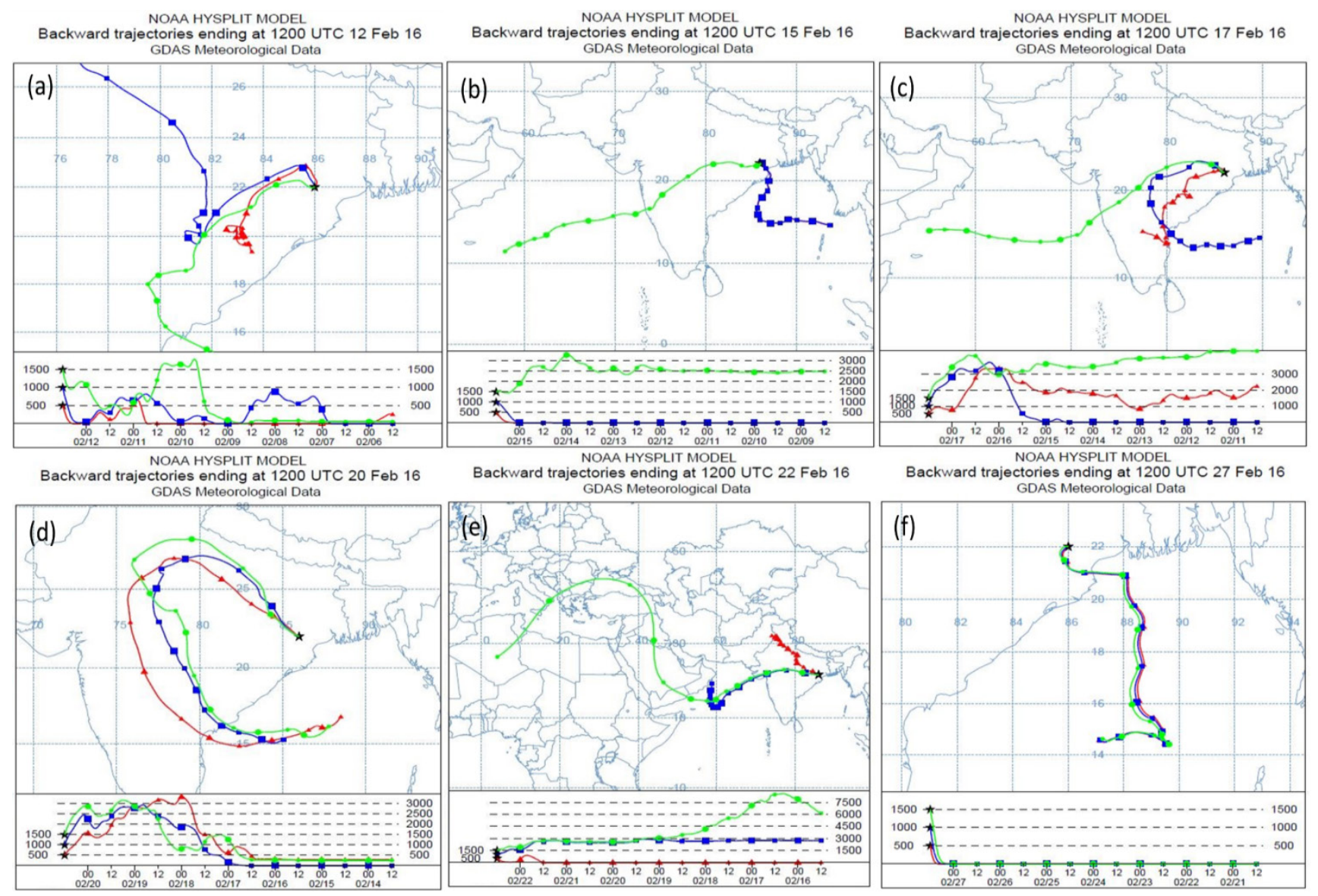

Fig. 6. Back trajectories reaching the measurement site with altitude $500 \mathrm{~m}$ above ground level (AGL) on (a) 12 , (b) 15 , (c) 17, (d) 20, (e) 22, and (f) 27 February 2016 (http://ready.arl.noaa.gov/HYSPLIT_traj.php).

with maximum values in the NMVMF region where AOD values of $0.6-1.6$ are observed in the pre-mature phase (Fig. 8(a)). AOD decreased (range: 0.4-1.2) in this region during the mature phase along with $f_{c}$ (Fig. 8(b)). The lesser values of $f_{c}$ signify stronger radiative effects (Koren et al., 2008) during the mature phase over NMVMF region, whereas substantial precipitation occurred in the dissipating phase (Fig. 4(c)). The absorption effects likely suppress the growth and formation of clouds (Adesina et al., 2016) during the mature phase. Absorption of solar radiation by aerosols may lead to evaporation as well. In the post-mature phase, AOD increased to 1.4 in the NMVMF area and $f_{c}$ values rose to 0.6 during the dissipating phase (Fig. 8(c)). The increase in $f_{c}$ values with AOD can induce a strong invigoration effect ( Niu and $\mathrm{Li}, 2012$ ), especially in the formation of new and deeper clouds (Small et al., 2009) during the dissipating phase in order to support the rainfall observed.

Mostly positive correlation is observed between AOD and $f_{c}$ over NMVMF, eastern (Odisha and Jharkhand) and northern parts of the Indian region considered in the premature phase (Fig. 8(d)). In the mature phase, correlations are negative in some parts of NMVMF region but again becomes significantly positive (up to 1 ) during the dissipating phase (Figs. 8(e)-8(f)). The significantly positive correlations $(0.4-1.0)$ between AOD and $f_{c}$ may be attributed to anthropogenic and dust aerosols transported to the region along with prevalent meteorological conditions. The negative correlations are likely resulting from the increase in $\mathrm{RH}$ with an increase in AOD, and probably due to more water vapor deposition on the particles (Myhre et al., 2007). The other possible reason could be the radiative absorption effect that is usually dominant with lower AOD and $f_{c}$ (Kang et al., 2015).

\section{Relationship between AOD and Cloud Effective Radius}

Fig. 9 depicts the spatial distribution and correlation between AOD, and ice and liquid CER over India during the pre-mature and dissipating phases of the unseasonal heatwave. Here, only the pre-mature and dissipating phases are considered since most of the clouds are formed in these phases.

Unavailability of data at several places for ice and liquid CER inhibited our ability in determining any significant relationship between them. However, in the dissipating phase, significant values of ice CER (ICER) were found mostly in the range 20-50 $\mu \mathrm{m}$ (Fig. 9(b)), indicating the likelihood of convective clouds. Ice clouds are high-level clouds, and aerosol effects on such clouds are less significant than they are for warm clouds (Jin and Shepherd, 2008). Thus, it becomes important to analyze the variation of liquid cloud effective radius (LCER). 


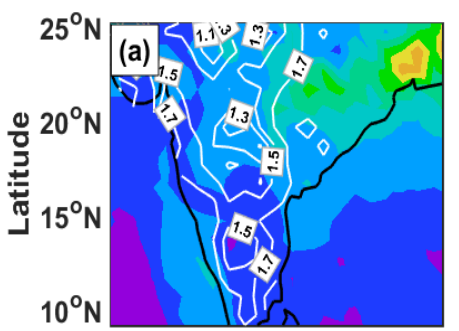

$70^{\circ} \mathrm{E} \quad 75^{\circ} \mathrm{E} 80^{\circ} \mathrm{E} 85^{\circ} \mathrm{E} 90^{\circ} \mathrm{E}$

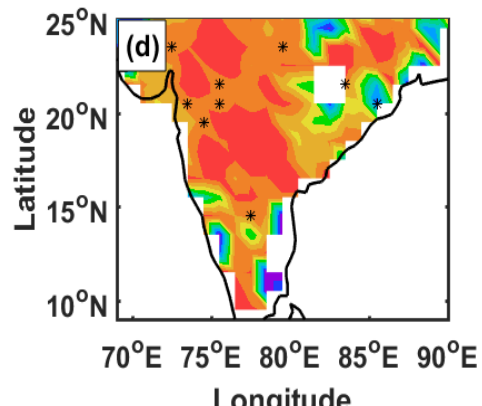

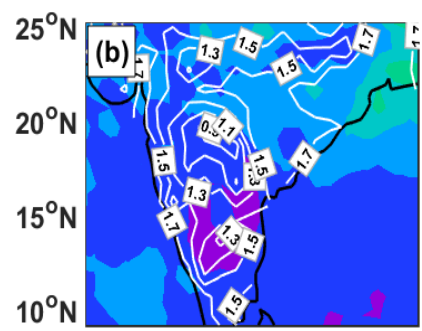

$70^{\circ} \mathrm{E} 75^{\circ} \mathrm{E} 80^{\circ} \mathrm{E} 85^{\circ} \mathrm{E} 90^{\circ} \mathrm{E}$

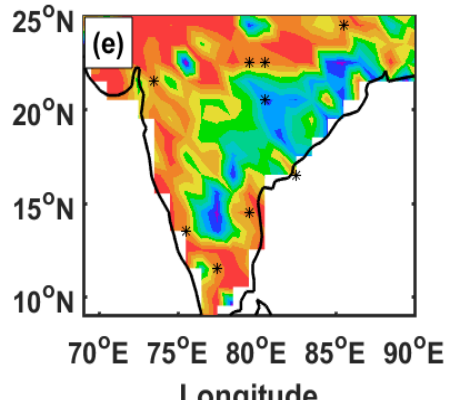

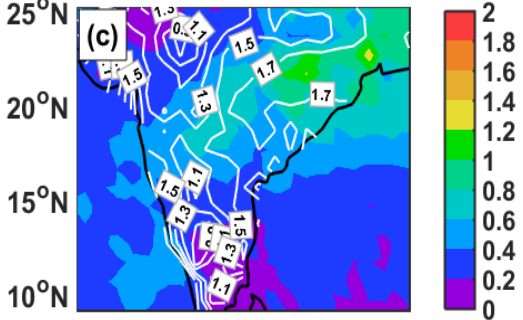

$70^{\circ} \mathrm{E} 75^{\circ} \mathrm{E} 80^{\circ} \mathrm{E} 85^{\circ} \mathrm{E} 90^{\circ} \mathrm{E}$

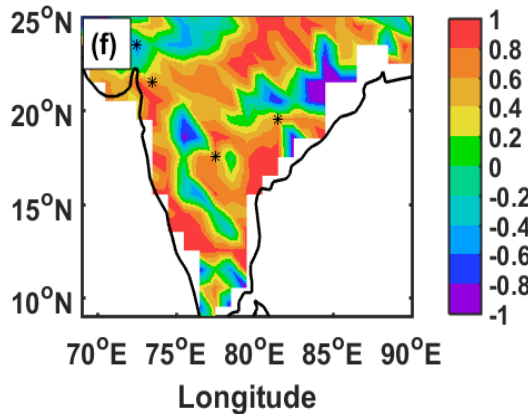

Fig. 7. The spatial distribution (top row) and correlation coefficient (bottom row) between Aerosol Optical Depth (AOD) and Ångström exponent, or AE $(0.412-0.47 \mu)$, during (a and d) pre-mature phase, (b and e) mature phase, and (c and f) dissipating phase of unseasonal heatwave condition over Indian region. The line contours are for AE and the shaded ones are for AOD. Asterisks show datasets are statistically significant at $95 \%$ confidence level. Here, MODIS data of $1^{\circ}$ resolution is considered.
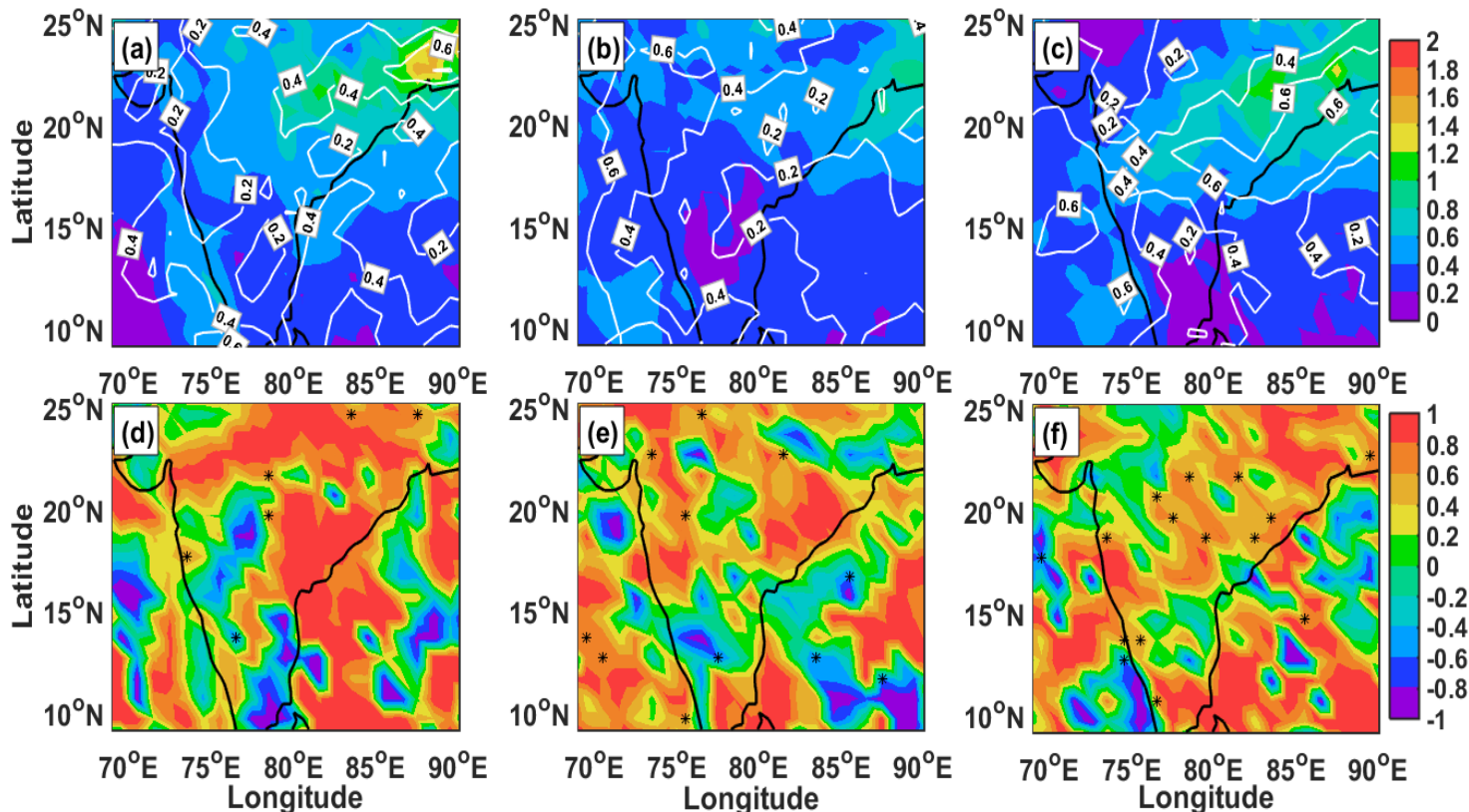

Fig. 8. The spatial distribution (top row) and correlation coefficient (bottom row) between AOD and cloud fraction ( $f_{c}$ ) during ( $a$ and $d$ ) pre-mature phase, ( $b$ and e) mature phase, and (c and $f$ ) dissipating phase of unseasonal heatwave condition over Indian region. The line contours are for cloud fraction and the shaded ones are for AOD. Asterisk indicates datasets are statistically significant at $95 \%$ confidence level. Here, MODIS data of $1^{\circ}$ resolution is considered.

Values of LCER ranged between 12-16 $\mu \mathrm{m}$ over NMVMF, accompanied by higher AOD values (up to 1.6) during the pre-mature phase (Fig. 9(c)). Moderate to the high amounts (0.6-1.4) of AOD with similar LCER (12$16 \mu \mathrm{m})$ found in the dissipating phase (Fig. 9(d)) indicate a favorable condition for the initiation of precipitation. This is because enhanced convection has the potential to initiate precipitation (Shepherd, 2005). In such a situation, convective clouds are formed by considering the moisture incursion from neighboring BOB (Fig. 2(c)), encouraged by the land-sea temperature contrast and prevailing wind pattern (Fig. 1; Jin and Shepherd, 2008). 
Positive correlation ( $>0.4)$ between AOD and LCER is observed in some parts of NMVMF during the pre-mature and dissipating phases (Figs. 9(e)-9(f)). A positive correlation between AOD and CER during rainfall episodes may signify the presence of slightly soluble organic particles and giant CCN (Yuan et al., 2008). The negative correlation between AOD and CER is due to significant aerosol loading leading to smaller CER (Twomey et al., 1984), which decreases the size of the cloud droplets (Jin and Shepherd, 2008).

\section{Relationship between Cloud Optical Depth and Cloud Top Temperature}

The attenuation of light passing through the atmosphere due to absorption and scattering from cloud droplets can be measured as COD. It can indirectly influence the surface and atmospheric radiation budget (Penner et al., 2004; Lubin and Vogelmann, 2011). CTT $(\mathrm{K})$ is a measure of the temperature at the level of cloud top, and it also plays a vital role in determining the net radiation budget of the earth (Adesina et al., 2016). The spatial distribution and correlation coefficient of COD and CTT during the premature and dissipating phases of the unseasonal heatwave is shown in Fig. 10. The values of COD are up to 28 with CTT in the range $280-290^{\circ} \mathrm{K}$ over NMVMF during the pre-mature phase (Fig. 10(a)). However, in the dissipating phase, the corresponding COD values increase up to 42 without much change in CTT (Fig. 10(b)). Mostly negative correlation $(-1.0$ to -0.2$)$ is observed between COD and CTT over NMVMF during the pre-mature phase (Fig. 10(c)). During the dissipating phase, the correlation coefficient ranges between -1.0 to 0.8 over the NMVMF (Fig. 10(d)). The asterisk in Figs. 10(c)-10(d) indicate that the dataset is statistically significant at the $95 \%$ significance level.

High amounts of moisture present in the atmosphere results in increased COD over NMVMF (Fig. 10(d)), which depends on the vertical depth and density of the clouds (Alam et al., 2010). The negative correlation is probably due to the presence of absorbing aerosols that encourage evaporation of cloud droplets (decrease in COD) and create relatively thin clouds (Alam et al., 2014). It indicates that cloud droplets are not growing bigger in size and an insufficient amount of water vapor or moisture is present inside the clouds. However, some of the clouds may grow to become relatively large, but might have insufficient liquid water content and thus are not capable of producing rainfall.

COD increases with AOD in the atmosphere and consequently reduces with CER (Fig. 9(c)) since the horizontal and vertical growth of clouds may not happen in the same time, which eventually impacts the cloud lifetime in the atmosphere (Twomey, 1977). In the dissipating phase, it is observed that a relative increase in COD (Fig. 10(b)) corresponds to a moisture incursion in the atmosphere (Fig. 2(c)) over NMVMF, which eventually helps in the formation of convective and precipitating clouds during the dissipating phase. The mature phase related discussion is limited here, due to unavailability of meaningful data.

\section{Relationship between AOD and Cloud Water Path}

Cloud water path (CWP) is the column-integrated liquid water inside the clouds. It is also one of the important parameters responsible for transporting energy in the form
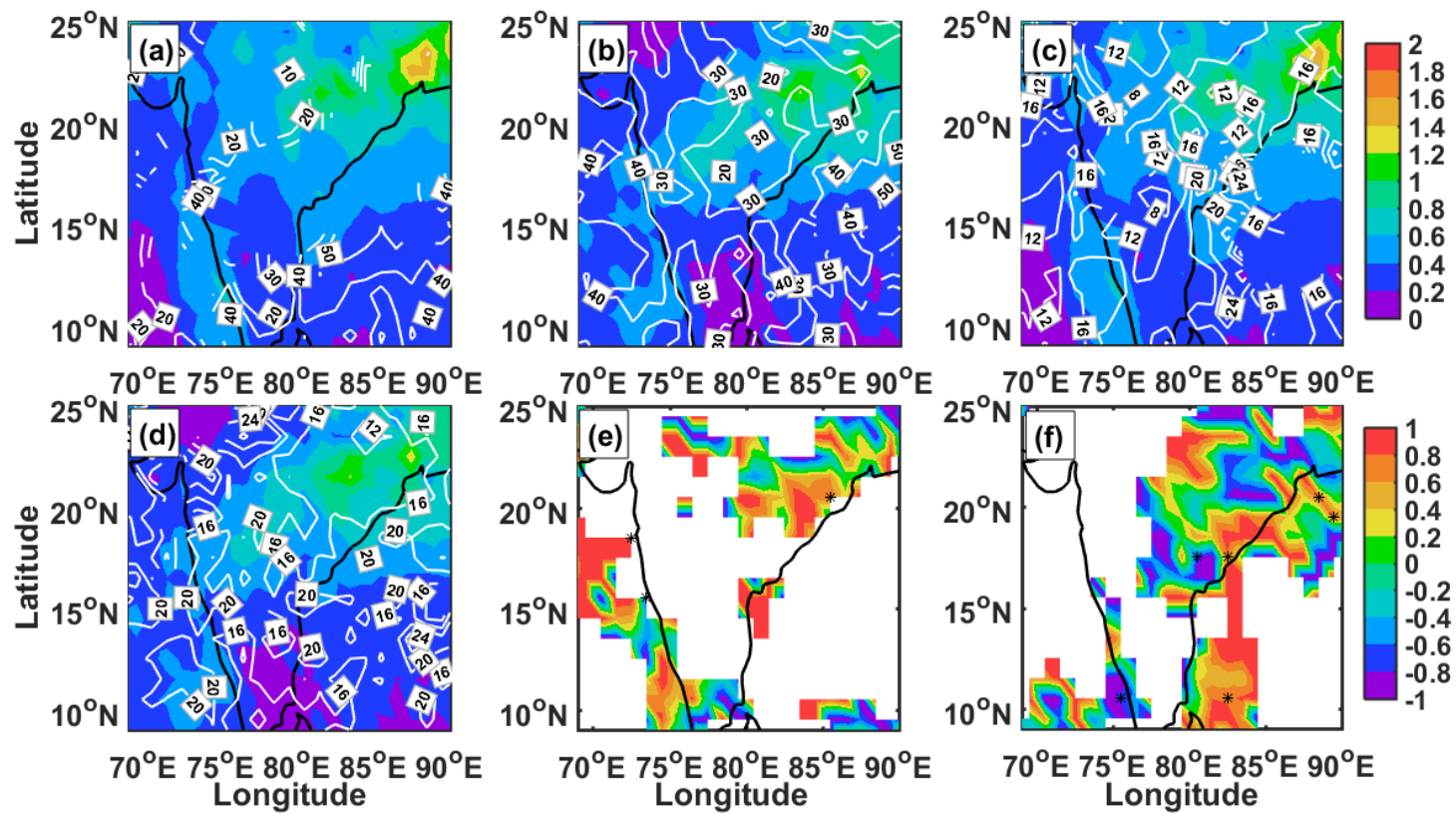

Fig. 9. The spatial distribution and correlation coefficient between AOD (shaded) and ice cloud effective radii, or ICER (contours), and liquid cloud effective radii, or LCER (contours), for unseasonal heatwave episode over Indian region during February 2016. AOD and ICER (in $\mu \mathrm{m}$ ) for: (a) pre-mature phase and (b) dissipating phase. AOD and LCER (in $\mu \mathrm{m})$ for: (c) pre-mature phase and (d) dissipating phase. Spatial variation in correlation coefficients between AOD and LCER are depicted in (e) and (f) for pre-mature and dissipating phases respectively. Asterisk indicates datasets are statistically significant at $95 \%$ confidence level. Here, MODIS data of $1^{\circ}$ resolution is considered. 

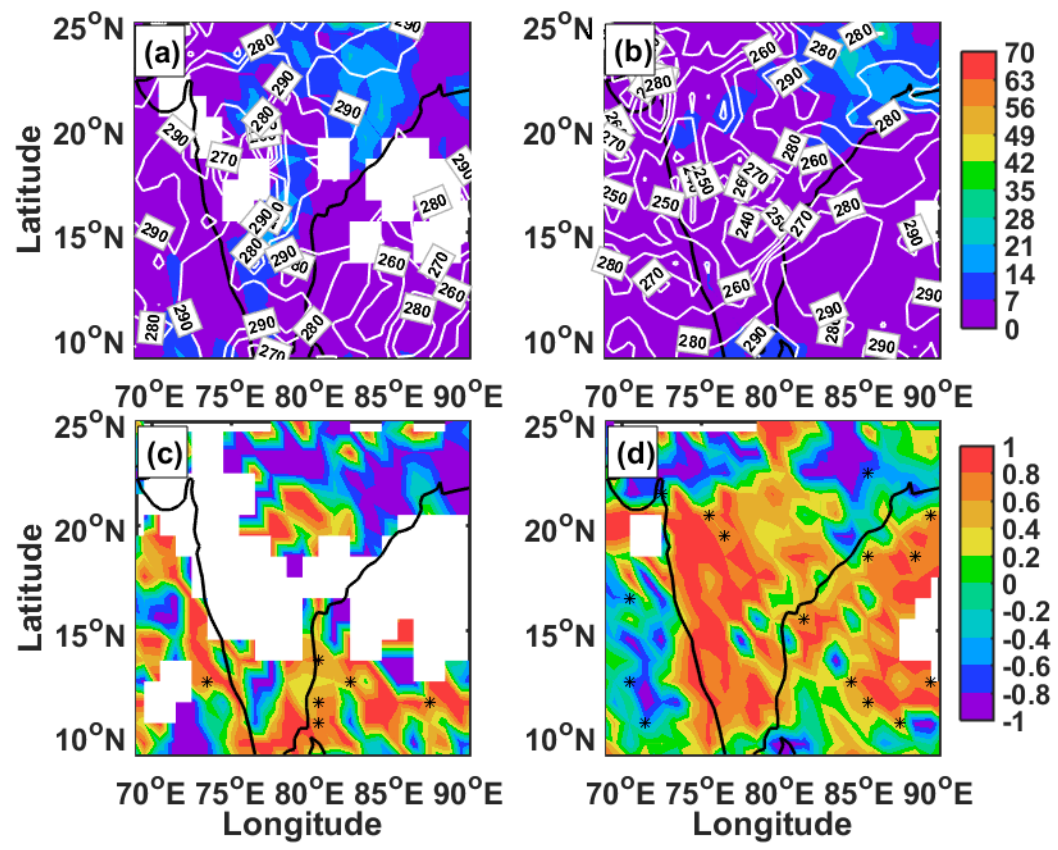

Fig. 10. The spatial distribution (top row) and correlation coefficient (bottom row) between Cloud Optical Depth (COD) and Cloud Top Temperature (CTT) in ${ }^{\circ} \mathrm{K}$ during (a) pre-mature phase and (b) dissipating phase of unseasonal heatwave condition over Indian region. The line contours represent CTT values whereas the shaded ones are for the COD distribution. Asterisk indicates datasets are statistically significant at $95 \%$ confidence level. Here, MODIS data of $1^{\circ}$ resolution is considered.

of latent heat in the earth-atmosphere system. Due to the unavailability of sufficient ice CWP (ICWP) data in the pre-mature phase (Fig. 11(a)), it is difficult to establish any relationship between AOD and ICWP. No meaningful relationship is noticed in the case of the mature phase (not shown) as well. In the dissipating phase, over NMVMF, where AOD values were in the range 0.4-1.4, significant ICWP values occurred within the range 200-800 $\mathrm{g} \mathrm{m}^{-2}$ (Fig. 11(b))

During the pre-mature phase in NMVMF, while AOD values vary up to 1.6 , reasonable liquid CWP (LCWP) values in the range $40-120 \mathrm{~g} \mathrm{~m}^{-2}$ are observed (Fig. 11(c)). However, the corresponding range of LCWP increases slightly up to $160 \mathrm{~g} \mathrm{~m}^{-2}$ over some areas in the dissipating phase (Fig. 11(d)), probably due to the prevailing meteorological condition (discussed earlier in Subsection 3.1). This indicates the increase in liquid water content inside the clouds during the dissipating phase, which probably helps drive precipitation processes, resulting in the major rainfall episode over NMVMF.

In the humid environment, the hygroscopic growth of aerosols is significant, with areas surrounded by clouds producing more numerous smaller cloud droplets (Kant et al., 2019a, b). The increase in aerosol loading may cause a reduction in droplet size, suppressing precipitation during the pre-mature and mature phases before raining out in the dissipating phase. Thus, in the earlier two phases, there is the prevalence of relatively appreciable LCWP. In addition, cloud formation includes both moisture availability and associated thermal and dynamical processes. The response of CWP is determined by the amount of water vapor present and lower tropospheric static stability (Savane et al., 2015). However, processes like moistening and drying may occur depending upon the variability in CWP with reasonable and favorable aerosol loading. In a low water vapor atmosphere, like that of the pre-mature and mature phases, aerosol loading happens to be undergoing a drying process, which then shifts to moistening in the dissipating phase due to the significant moisture incursion to the NMVMF atmosphere correspondingly enhancing the range and relatively high value of CWP.

It is difficult to draw any conclusion for the correlation between AOD and ICWP due to unavailability of ICWP data. Over NMVMF, mostly negative or slightly positive correlation is observed between AOD and LCWP during the pre-mature and dissipating phases (Figs. 11(e)-11(f)). However, some areas in NMVMF show a strongly positive correlation (up to 1.0) in the pre-mature phase (Fig. 11(e)). The negative correlation between AOD and LCWP during the dissipating phase contradicted the aerosol indirect effect (Alam et al., 2014). Water-soluble aerosols grow due to water uptake and humidity swelling (Storelvmo et al., 2006). This growth depends upon the presence of a reasonable amount of moisture in the atmosphere, and consequently, aerosols become optically thicker (Alam et al., 2014). The mechanism should lead to the positive correlation between AOD and LCWP. Therefore, it is quite challenging to explain this contradictory relationship.

\section{CONCLUDING REMARKS}

The aerosol-cloud-precipitation (ACP) interaction over 

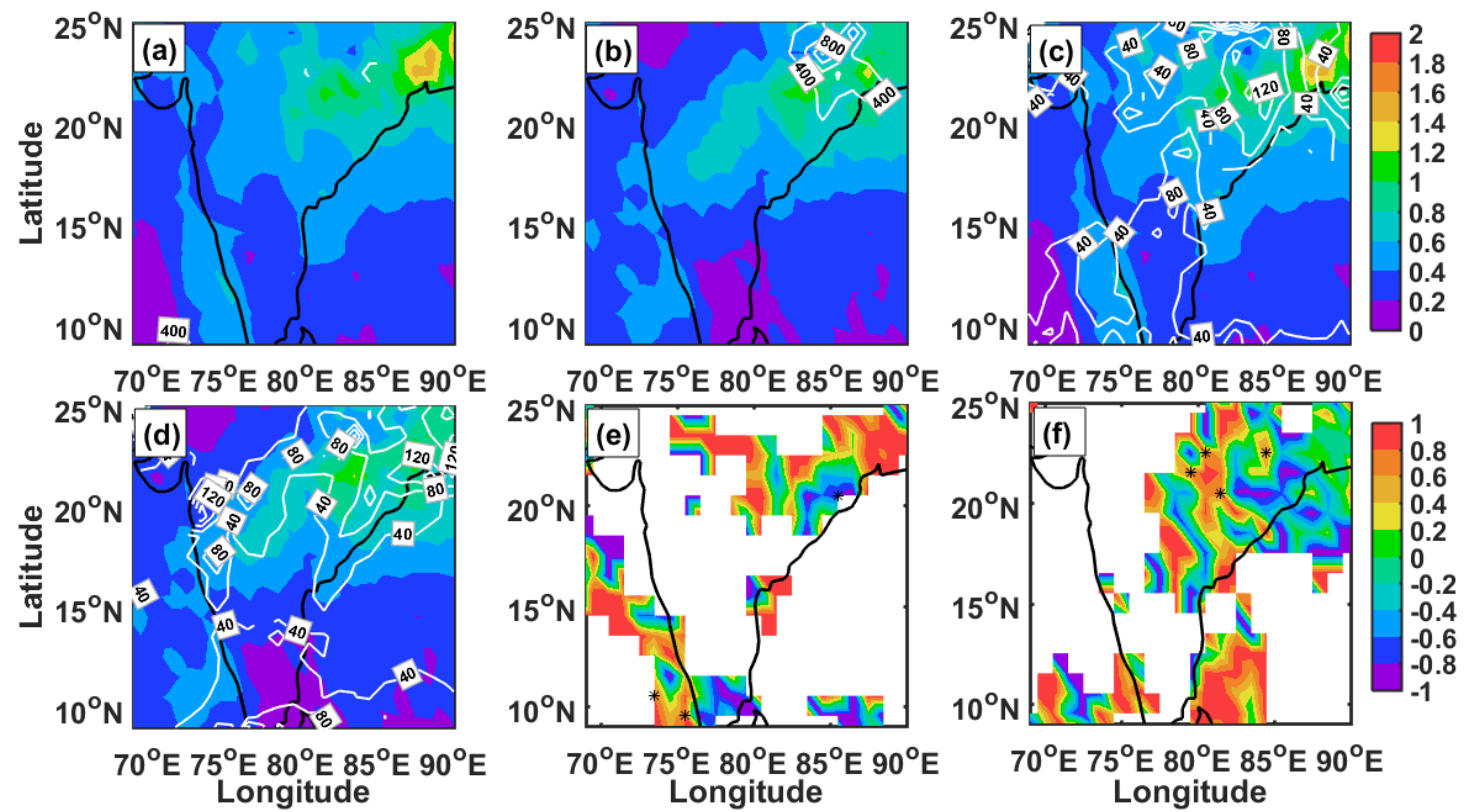

Fig. 11. The spatial distribution and correlation coefficient between AOD (shaded), ice cloud water path, or ICWP (contours), and liquid cloud water path, or LCWP (contours), for unseasonal heatwave episode over Indian region during February 2016. AOD and ICWP for: (a) pre-mature phase and (b) dissipating phase. AOD and LCWP for: (c) pre-mature phase and (d) dissipating phase. Spatial variation in correlation coefficients between AOD and LCWP are depicted in (e) and (f) for pre-mature and dissipating phases respectively. Asterisks are indicative of datasets with $95 \%$ significance. Here, MODIS data of $1^{\circ}$ resolution is considered.

the Indian peninsula (Fig. 12) during the three phases of an unseasonal heatwave in February 2016 was investigated by analyzing MODIS, TRMM, and ERA-Interim datasets. Although the temperature was relatively low during the pre-mature phase, the prevailing hot and dry westerly winds eventually gained strength, resulting in a temperature increase over the study region during the mature phase. The maximum temperature and the area it affected gradually increased during the dissipating phase.

The vertically integrated moisture flux convergence was low over a distinct region extending from the south-western to the eastern areas of India during all three phases, despite the expectation of active convection. A moderate to maximum vertically integrated moisture flux was identified in the area to the north of the minimum vertically integrated moisture flux (NMVMF) located in north-eastern and eastern India (basically, northern Odisha, eastern Jharkhand, and most of the adjoining parts of West Bengal). During the dissipating phase, high relative humidity $(\mathrm{RH})$ was observed near the coastal regions, especially the NMVMF $\left(19-24^{\circ} \mathrm{N}, 80-90^{\circ} \mathrm{E}\right)$, due to the incursion of moisture from the neighboring Bay of Bengal (BOB), which was aided by easterly and south-easterly winds arising from the land-sea temperature contrast. The moisture flux convergence over the NMVMF indicates favorable conditions for instability and thus the convective initiation processes required for cloud growth, specifically, stronger updrafts that drag the supplied moisture upward, leading to increased cloud droplet size (Fig. 12). The favorable meteorological conditions, convection within the atmospheric boundary layer, and prevailing characteristics of the underlying land surface help produce warm air advection, resulting in a specific regional circulation pattern (Panda et al., 2009; Panda and Sharan, 2012; Li et al., 2016). The collective effect is accelerated convection (Banacos and Schultz, 2005) over the study area, which may enhance the formation of convective clouds and promote the initiation of precipitation over the NMVMF (Fig. 12).

MODIS satellite images and back trajectory analysis indicate that westerly winds transported aerosols from the western side of Asia and the Arabian Sea to India (Tripathi et al., 2005). Since aerosols can play a substantial role in determining cloud characteristics and the consequent rainfall, the aerosol characteristics and cloud parameters were analyzed along with the relevant meteorological parameters.

Over the NMVMF, the cloud fraction $\left(f_{c}\right)$ increased (decreased) with the aerosol optical depth (AOD) during the pre-mature (mature) phase, suggesting strong radiative or semi-indirect effects from aerosols (Koren et al., 2008), and the absorption of solar radiation by cloud droplets, which consequently suppressed precipitation. On the other hand, the significantly positive relationship between the $f_{c}$ and the AOD during the dissipating phase indicates an invigorating effect (Niu and $\mathrm{Li}, 2012$ ) that encourages the formation and growth of larger cloud droplets due to sufficient moisture. The liquidLiquid cloud effective radius (LCER) over the NMVMF increased with the AOD during the dissipating phase. Increased $\mathrm{CCN}$ aid the convective precipitation process. The relatively high values of the LCER during the dissipating phase, supported by the moderate to high AOD values, promoted convection and moisture incursion through a regional dynamical process 


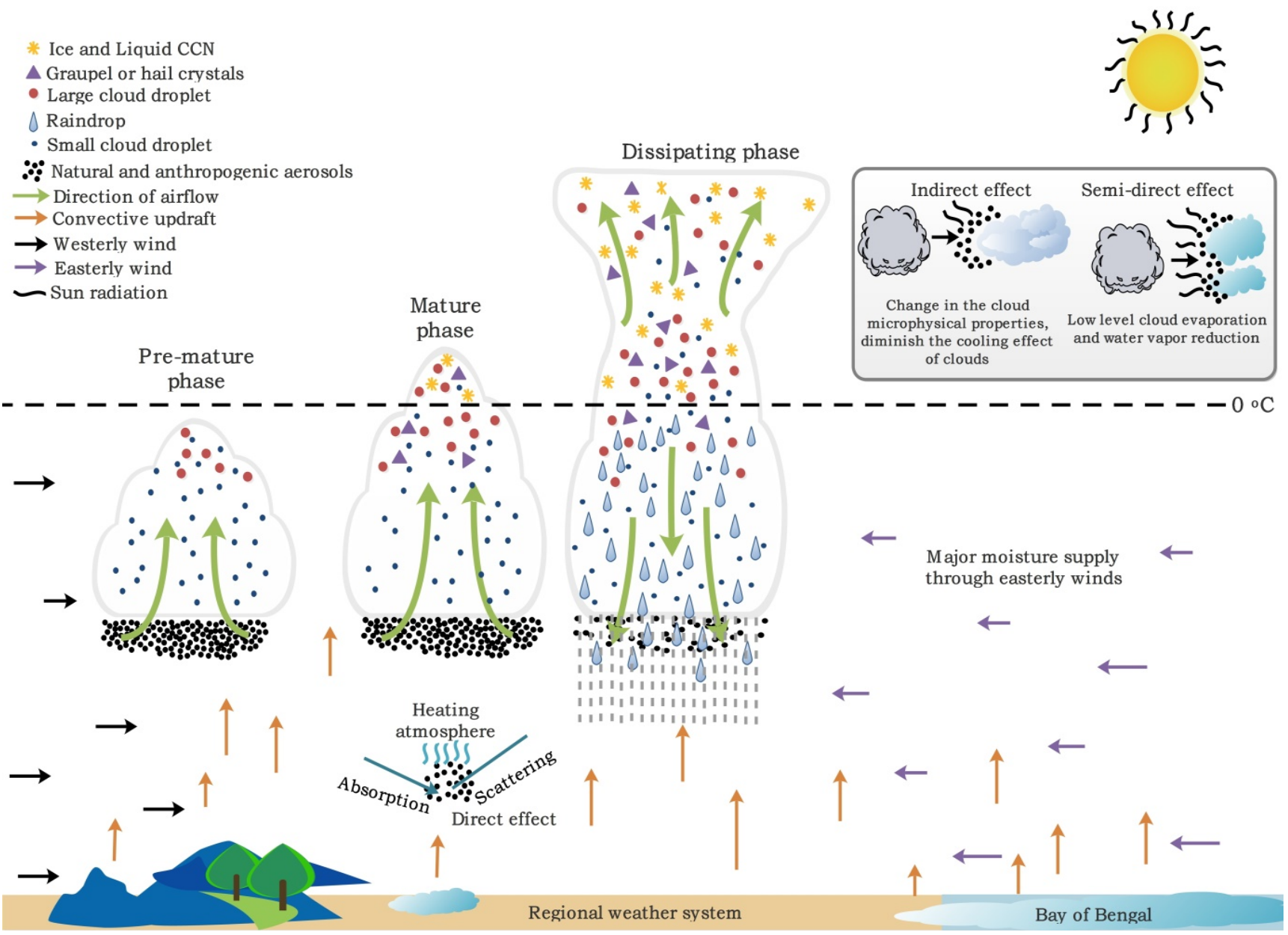

Fig. 12. Schematic diagram representing aerosol-cloud-precipitation interaction during February 2016 unseasonal heatwave episode that occurred over India.

that favors rainfall. The positive AOD-LCER relationship over parts of the NMVMF during the pre-mature and dissipating phases indicates the significant role of dynamical, thermo-dynamical, and microphysical effects on cloud droplets (Kang et al., 2015). This anti-Twomey effect over the cloud effective radius (CER) may be due to the complex composition of aerosols and the flaws in satellite retrieval methods (Li et al., 2011; Wang et al., 2014). However, a negative AOD-CER relationship, irrespective of meteorological conditions with greater aerosol presence, leads to a smaller CER over some land areas (Twomey et al., 1984), which is congruous with the Twomey effect (Twomey, 1977). Thus, aerosols tend to experience either the Twomey or the anti-Twomey effect over land during unstable conditions (Wang et al., 2014).

The lower cloud optical depth (COD) over the NMVMF during the pre-mature phase suggests that optically thinner clouds (Alam et al., 2014) form when aerosols are present, possibly because of the enhanced evaporation of cloud droplets (a semi-direct effect of aerosols). During the dissipating phase, the COD increased without noticeable change in the cloud top temperature (CTT), and the negative COD-CTT relationship that had been observed during the pre-mature phase became positive over some areas.
Aerosol loading may have decreased evapotranspiration or the microphysical effects (Niu and Li, 2012), resulting in reduced liquid cloud water content during the pre-mature phase. However, during the mature phase, hot and dry westerly winds increased the near-surface temperature, thereby strengthening convectively driven liquid water updrafts in the atmosphere - the invigorating effect (Niu and Li, 2012) - and promoting cloud droplet growth. Therefore, sufficient liquid water content supplied to the convective clouds (shown by the liquid cloud water path (LCWP)) during the dissipating phase over the NMVMF was probably responsible for the occurrence of precipitation. A contradictory aerosol response to the cloud water path (CWP) was detected over the NMVMF, partly due to insufficient ice CWP data and to the mostly negative AOD-LCWP relationship.

The clouds' response to aerosols during the February 2016 unseasonal heatwave episode reveals the combined effects of dynamic, thermodynamic, and microphysical processes (Fig. 12). Due to the prevalent dynamic and thermodynamic atmospheric conditions, the observed cloud characteristics cannot be completely attributed to the presence of aerosols. Hence, it is difficult to distinguish the role of aerosols from that of meteorology in determining 
cloud properties and precipitation over India during an extreme weather event, and more case studies, including a significant amount of observation as well as a better understanding of relevant physical processes, are required.

\section{ACKNOWLEDGMENTS}

The authors are obliged to NOAA-ARL for HYSPLIT transport and dispersion model for computing the back trajectory; the datasets are taken from Aqua-MODIS (http://giovanni.sci.gsfc.nasa.gov/giovanni/), Wyoming Weather Web (http://weather.uwyo.edu), ERA-Interim portal (http://apps.ecmwf.int/datasets) and air mass transport image (http://modisatmos.gsfc.nasa.gov/IMAGES/index.html) for the analysis purpose. Special thanks go to our friends Sudhansu Sekhar Rath, Kasturi Singh and Bijay Kumar Guha for their valuable support during my work. We are thankful to the reviewers for their valuable feedback that helped in the overall improvement of the manuscript.

\section{REFERENCES}

Adesina, A.J., Kumar, K.R. and Sivakumar, V. (2016). Aerosol-cloud-precipitation interactions over major cities in South Africa: Impact on regional environment and climate change. Aerosol Air Qual. Res. 16: 195211, doi: 10.4209/aaqr.2015.03.0185.

Alam, K., Iqbal, M.J., Blaschke, T., Qureshi, S. and Khan, G. (2010). Monitoring spatio-temporal variations in aerosols and aerosol-cloud interactions over Pakistan using MODIS data. Adv. Space Res. 46: 1162-1176, doi: 10.1016/j.asr.2010.06.025.

Alam, K., Khan, R., Blaschke, T. and Mukhtiar, A. (2014). Variability of aerosol optical depth and their impact on cloud properties in Pakistan. J. Atmos. Sol. Terr. Phys. 107: 104-112, doi: 10.1016/j.jastp.2013.11.012.

Albrecht, B.A. (1989). Aerosols, cloud microphysics, and fractional cloudiness. Science 245: 1227-1230, doi: 10.1126/science.245.4923.1227.

Alishouse, J.C., Snider, J.B., Westwater, E.R., Swift, C.T., Ruf, C.S., Snyder, S.A., Vongsathorn, J. and Ferraro, R.R. (1990). Determination of cloud liquid water content using the SSM/I. IEEE Geosci. Remote Sens. Lett. 28: 817-822, doi: 10.1109/36.58968.

Altaratz, O., Koren, I., Reisin, T., Kostinski, A., Feingold, G., Levin, Z. and Yin, Y. (2008). Aerosols' influence on the interplay between condensation, evaporation and rain in warm cumulus cloud. Atmos. Chem. Phys. 8: 1524, doi: 10.5194/acp-8-15-2008.

Banacos, P.C. and Schultz, D.M. (2005). The use of moisture flux convergence in forecasting convective initiation: Historical and operational perspectives. Weather Forecasting 20: 351-366, doi: 10.1175/WAF858.1.

Bhadram, C.V.V., Amatya, B.V.S., Pant, G.B. and Kumar, K.K. (2005). Heat waves over Andhra Pradesh: A case study of summer 2003. Mausam 56: 385-394.

Bhawar, R.L. and Devara, P.C.S. (2010). Study of successive contrasting monsoons (2001-2002) in terms of aerosol variability over a tropical station Pune, India.
Atmos. Chem. Phys. Discuss. 9: 6957-6977, doi: 10.5194/acpd-9-6957-2009.

Cheng, W.Y., Carrió, G.G., Cotton, W.R. and Saleeby, S.M. (2009). Influence of cloud condensation and giant cloud condensation nuclei on the development of precipitating trade wind cumuli in a large eddy simulation. J. Geophys. Res. 114: D08201, doi: 10.1029/2008JD011011.

Confalonieri, U., Menne, B., Akhtar, R., Ebi, K., Hauengue, M., Kovats, R.S., Revich, B. and Woodward, A. (2007). Human health. In Climate Change 2007: Impacts, Adaptation and Vulnerability. Contribution of Working Group II to the Fourth Assessment Report of the Intergovernmental Panel on Climate Change. Parry, M., Canziani, O., Palutikof, J., van der Linden, P. and Hanson, C. (Eds.), Cambridge University Press, Cambridge, pp. 391-431.

Dagan, G., Koren, I. and Altaratz, O. (2015). Aerosol effects on the timing of warm rain processes. Geophys. Res. Lett. 42: 4590-4598, doi: 10.1002/2015GL063839.

De, U.S. and Mukhopadhyay, R.K. (1998). Severe heat wave over the Indian subcontinent in 1998, in perspective of global climate. Curr. Sci. 75: 1308-1311.

Draxler, R.R. and Rolph, G.D. (2003). HYSPLIT (HYbrid Single-Particle Lagrangian Integrated Trajectory) model access via NOAA ARL READY website (http://www.arl. noaa.gov/ready/hysplit4.html). NOAA Air Resources Laboratory, Silver Spring.

Feingold, G., Cotton, W.R., Kreidenweis, S.M., Davis, J.T. and Avis, J.A.T.D. (1999). The impact of giant cloud condensation nuclei on drizzle formation in stratocumulus: Implications for cloud radiative properties. J. Atmos. Sci. 56: 4100-4117.

Felton, C.S., Subrahmanyam, B. and Murty, V.S.N. (2013). ENSO-modulated cyclogenesis over the Bay of Bengal. J. Clim. 26: 9806-9818.

Gautam, R., Hsu, N.C., Tsay, S.C., Lau, K.M., Holben, B., Bell, S., Smirnov, A., Li, C., Hansell, R., Ji, Q., Payra, S., Aryal, D., Kayastha, R. and Kim, K.M. (2011). Accumulation of aerosols over the Indo-Gangetic plains and southern slopes of the Himalayas: Distribution, properties and radiative effects during the 2009 premonsoon season. Atmos. Chem. Phys. 11: 12841-12863, doi: 10.5194/acp-11-12841-2011.

Ghatak, D., Zaitchik, B., Hain, C. and Anderson, M. (2017). The role of local heating in the 2015 Indian Heat Wave. Sci. Rep. 7: 7707.

Guha, B.K., Chakraborty, R., Saha, U. and Maitra, A. (2017). Tropopause height characteristics associated with ozone and stratospheric moistening during intense convective activity over India sub-continent. Global Planet. Change 158: 1-12.

Gunn, R. and Phillips, B.B. (1957). An experimental investigation of the effect of air pollution on the initiation of rain. J. Meteorol. 14: 272-280, doi: 10.1175/15200469(1957)014<0272:AEIOTE $>2.0 . C O ; 2$.

Houghton, H.G. (1938). Problems connected with the condensation and precipitation processes in the atmosphere. Bull. Am. Meteorol. Soc. 19: 152-159.

Hudson, J.G. and Mishra, S. (2007). Relationships between 
$\mathrm{CCN}$ and cloud microphysics variations in clean maritime air. Geophys. Res. Lett. 34: L16804, doi: 10.1029/2007GL030044.

IPCC (2007). Climate Change 2007: The physical science basis. Contribution of Working Group I to the Fourth Assessment Report of the Intergovernmental Panel on Climate Change. Solomon, S., Qin, D., Manning, M., Chen, Z., Marquis, M., Averyt, K.B., Tignor, M. and Miller, H.L. (Eds.), Cambridge University Press, Cambridge, UK and New York, NY, USA.

Jain, S.K. and Kumar, V. (2012). Trend analysis of rainfall and temperature data for India. Curr. Sci. 102: 37-49.

Jiang, H. and Feingold, G. (2006). Effect of aerosol on warm convective clouds: Aerosol-cloud surface flux feedbacks in a new coupled large eddy model. J. Geophys. Res. 111: D01202, doi: 10.1029/2005JD006138.

Jiang, H., Xue, H., Teller, A., Feingold, G. and Levin, Z. (2006). Aerosol effects on the lifetime of shallow cumulus. Geophys. Res. Lett. 33: L14806, doi: 10.1029/ 2006 GL026024.

Jin, M. and Shepherd, J.M. (2008). Aerosol relationships to warm season clouds and rainfall at monthly scales over east China: Urban land versus ocean. J. Geophys. Res. 113: 1-12, doi: 10.1029/2008JD010276.

Johnson, D.B. (1982). The role of giant and ultragiant aerosol particles in warm rain initiation. J. Atmos. Sci. 39: 448-460.

Jung, T., Ruprecht, E. and Wagner, F. (1998). Determination of cloud liquid water path over the oceans from Special Sensor Microwave/Imager (SSM/I) data using neural networks. J. Appl. Meteorol. 37: 832-844.

Kang, N., Kumar, K.R., Yin, Y., Diao, Y. and Yu, X. (2015). Correlation analysis between AOD and cloud parameters to study their relationship over China using MODIS data (2003-2013): Impact on cloud formation and climate change. Aerosol Air Qual. Res. 15: 958-973.

Kant, S., Panda, J., Gautam, R., Wang, P.K. and Singh, S.P. (2017). Significance of aerosols influencing weather and climate over Indian region. Int. J. Earth. Atmos. Sci. 4: 1-20.

Kant, S., Panda, J. and Gautam, R. (2019a). A seasonal analysis of aerosol-cloud-radiation interaction over Indian region during 2000-2017. Atmos. Environ. 201: 212-222.

Kant, S., Panda, J., Pani, S.K. and Wang, P.K. (2019b). Long-term study of aerosol-cloud-precipitation interaction over the eastern part of India using satellite observations during pre-monsoon season. Theor. Appl. Climatol. 136: 605-626, doi: 10.1007/s00704-018-2509-2.

Khain, A.P. (2009). Notes on state-of-the-art investigations of aerosol effects on precipitation: A critical review. Environ. Res. Lett. 4: 15004, doi: 10.1088/1748-9326/4/ $1 / 015004$.

Kidder, S.Q. and Vonder Haar, T.H. (1995). Satellite meteorology: An introduction. Gulf Professional Publishing.

King, M.D., Kaufman, Y.J., Tanré, D. and Nakajima, T. (1999). Remote sensing of tropospheric aerosols from space: Past, present, and future. Bull. Am. Meteorol. Soc.
80: 2229-2259.

King, M.D., Tsay, S.C., Platnick, S.E., Wang, M. and Liou, K.N. (1997). Cloud retrieval algorithms for MODIS: Optical thickness, effective particle radius, and thermodynamic phase. MODIS Algorithm Theoretical Basis Document, Goddard Space Flight Center, NASA, USA.

Koren, I. (2005). Aerosol invigoration and restructuring of Atlantic convective clouds. Geophys. Res. Lett. 32: L14828, doi: 10.1029/2005GL023187.

Koren, I., Altaratz, O., Remer, L.A., Feingold, G., Martins, J.V. and Heiblum, R.H. (2012). Aerosol-induced intensification of rain from the tropics to the mid-latitudes. Nat. Geosci. 5: 118-122, doi: 10.1038/ngeo1364.

Koren, I., Dagan, G. and Altaratz, O. (2014). From aerosollimited to invigoration of warm convective clouds. Science 344: 1143-1146, doi: 10.1126/science. 1252595.

Koren, I., Feingold, G. and Remer, L.A. (2010). The invigoration of deep convective clouds over the Atlantic: Aerosol effect, meteorology or retrieval artifact? Atmos. Chem. Phys. 10: 8855-8872, doi: 10.5194/acp-10-88552010.

Koren, I., Kaufman, Y.J., Remer, L.A. and Martins, J.V. (2004). Measurement of the effect of Amazon smoke on inhibition of cloud formation. Science 303: 1342-1345, doi: $10.1126 /$ science. 1089424 .

Koren, I., Martins, J.V., Remer, L.A. and Afargan, H. (2008). Smoke invigoration versus inhibition of clouds over the Amazon. Science 321: 1-5, doi: 10.1007/s13398014-0173-7.2.

Lasher-Trapp, S.G., Knight, C.A. and Straka, J.M. (2001). Early radar echoes from ultragiant aerosol in a cumulus congestus: Modeling and observations. J. Atmos. Sci. 58: 3545-3562.

Li, X.X., Koh, T.Y., Panda, J. and Norford, L.K. (2016). Impact of urbanization patterns on the local climate of a tropical city Singapore: An ensemble study. J. Geophys. Res. 121: 4386-4403.

Li, Z., Niu, F., Fan, J., Liu, Y., Rosenfeld, D. and Ding, Y. (2011). Long-term impacts of aerosols on the vertical development of clouds and precipitation. Nat. Geosci. 4: 888-894, doi: 10.1038/ngeo1313.

Loeb, N.G. and Schuster, G.L. (2008). An observational study of the relationship between cloud, aerosol and meteorology in broken low-level cloud conditions. $J$. Geophys. Res. 113: D14214.

Lubin, D. and Vogelmann, A.M. (2011). The influence of mixed-phase clouds on surface shortwave irradiance during the Arctic spring. J. Geophys. Res. 116: D00T05.

Menzel, W.P. and Strabala, K.I. (1997). Cloud top properties and cloud phase algorithm theoretical basis document. University of Wisconsin-Madison, USA.

Metaxas, D.A. and Kallos, G. (1980). Heat waves from a synoptic point of view. Rivista Meteor. Aeronaut. 40: 107-119.

Minnis, P., Ayers, J.K., Palikonda, R. and Phan, D. (2004). Contrails, cirrus trends, and climate. J Clim. 17: 16711685.

Mishra, V., Ganguly, A.R., Nijssen, B. and Lettenmaier, 
D.P. (2015). Changes in observed climate extremes in global urban areas. Environ. Res. Lett. 10: 24005, doi: 10.1088/1748-9326/10/2/024005.

Mishra, V., Mukherjee, S., Kumar, R. and Stone, D.A., 2017. Heat wave exposure in India in current, $1.5^{\circ} \mathrm{C}$, and $2.0^{\circ} \mathrm{C}$ worlds. Environ .Res. Lett. 12: 124012.

Myhre, G., Stordal, F., Johnsrud, M., Kaufman, Y.J., Rosenfeld, D., Storelvmo, T., Kristjansson, J.E., Berntsen, T.K., Myhre, A. and Isaksen, I.S. (2007). Aerosol-cloud interaction inferred from MODIS satellite data and global aerosol models. Atmos. Chem. Phys. 7: 3081-3101.

Niu, F. and Li, Z. (2012). Systematic variations of cloud top temperature and precipitation rate with aerosols over the global tropics. Atmos. Chem. Phys. 12: 8491-8498.

Noh, Y.C., Sohn, B.J., Kim, Y., Joo, S. and Bell, W. (2016). Evaluation of temperature and humidity profiles of Unified Model and ECMWF analyses using GRUAN radiosonde observations. Atmosphere 7: 1-13.

Oldenborgh, G.J.V., Philip, S., Kew, S., Weele, M.V., Uhe, P., Otto, F., Singh, R., Pai, I., Cullen, H. and AchutaRao, K. (2018). Extreme heat in India and anthropogenic climate change. Nat. Hazards Earth Syst. Sci. 18: 365-381.

Panda, J. and Sharan, M. (2012). Influence of land-surface and turbulent parameterization schemes on regionalscale boundary layer characteristics over northern India. Atmos. Res. 112: 89-111.

Panda, J., Sharan, M. and Gopalakrishnan, S.G. (2009). Study of regional-scale boundary layer characteristics over northern India with a special reference to the role of the Thar Desert in regional scale transport. J. Appl. Meteorol. 48: 2377-2402.

Panda, J., Singh, H., Wang, P.K., Giri, R.K. and Routray, A. (2015). A qualitative study of some meteorological features during tropical cyclone PHET using satellite observations and WRF modeling system. J. Indian Soc. Remote 43: 45-56.

Patidar, V., Tripathi, S.N., Bharti, P.K. and Gupta, T. (2012). First surface measurement of cloud condensation nuclei over Kanpur, IGP: Role of long range transport. Aerosol Sci. Technol. 46: 973-982.

Pattanaik, D.R., Mohapatra, M., Srivastava, A.K. and Kumar, A. (2017). Heat wave over India during summer 2015: An assessment of real time extended range forecast. Meteorol. Atmos. Phys. 129: 375-393.

Penner, J.E., Dong, X.Q. and Chen, Y. (2004). Observational evidence of a change in radiative forcing due to the indirect aerosol effect. Nature 427: 231-234, doi: 10.1038/nature02234.

Pinsky, M., Khain, A.P., Magaritz, L. and Sterkin, A. (2008). Simulation of droplet size distributions and drizzle formation using a new trajectory ensemble model of cloud topped boundary layer. Part 1: Model description and first results in non-mixing limit. $J$. Atmos. Sci. 65: 2064-2086.

Pinsky, M., Mazin, I.P., Korolev, A. and Khain, A. (2013). Supersaturation and diffusional droplet growth in liquid clouds. J. Atmos. Sci. 70: 2778-2793.
Platnick, S., King, M.D., Ackerman, S.A., Menzel, W.P., Baum, B.A., Riédi, J.C. and Frey, R.A. (2003). The MODIS cloud products: Algorithms and examples from terra. IEEE Trans. Geosci. Remote Sens. 41: 459-472, doi: 10.1109/TGRS.2002.808301.

Rajeev, K., Ramanathan, V. and Meywerk, J. (2000). Regional aerosol distribution and its long-range transport over the Indian Ocean. J. Geophys. Res. 105: 2029, doi: 10.1029/1999JD900414.

Ratnam, J.V., Behera, S.K., Ratna, S.B., Rajeevan, M. and Yamagata, T. (2016). Anatomy of Indian heatwaves. Sci. Rep. 6: 24395, doi: 10.1038/srep24395.

Remer, L.A., Kaufman, Y.J., Tanré, D., Mattoo, S., Chu, D.A., Martins, J.V., Li, R.R., Ichoku, C., Levy, R.C., Kleidman, R.G. and Eck, T.F. (2005). The MODIS aerosol algorithm, products, and validation. J. Atmos. Sci. 62: 947-973.

Rosenfeld, D. (1999). TRMM observed first direct evidence of smoke from forest fires inhibiting rainfall. Geophys. Res. Lett. 26: 3105-3108, doi: 10.1029/1999GL006066.

Rosenfeld, D. and Lensky, I.M. (1998). Satellite-based insights into precipitation formation processes in continental and maritime convective clouds. Bull. Am. Meteorol. Soc. 79:2457-2476, doi: 10.1175/1520-0477 (1998) $079<2457:$ SBIIPF $>2.0 . C O ; 2$.

Sarna, K. and Russchenberg, H.W. (2017). Monitoring aerosol-cloud interactions at the CESAR Observatory in the Netherlands. Atmos. Meas. Tech. 10: 1987-1997.

Savane, O.S., Vant-Hull, B., Mahani, S. and Khanbilvardi, R. (2015). Effects of aerosol on cloud liquid water path: Statistical method a potential source for divergence in past observation based correlative studies. Atmosphere 6: 273-298.

Sayer, A.M., Hsu, N.C., Bettenhausen, C., Lee, J., Redemann, J., Schmid, B. and Shinozuka, Y. (2016). Extending "Deep Blue" aerosol retrieval coverage to cases of absorbing aerosols above clouds: Sensitivity analysis and first case studies. J. Geophys. Res. 121: 4830-4854.

Segal, Y. and Khain, A. (2006). Dependence of droplet concentration on aerosol conditions in different cloud types: Application to droplet concentration parameterization of aerosol conditions. J. Geophys. Res. 111: D15204, doi: 10.1029/2005JD006561.

Shepherd, J.M. (2005). A review of current investigations of urban-induced rainfall and recommendations for the future. Earth Interact 9: 1-27.

Small, J.D., Chuang, P.Y., Feingold, G. and Jiang, H. (2009). Can aerosol decrease cloud lifetime? Geophys. Res. Lett. 36: L16806, doi: 10.1029/2009GL038888.

Squires, P. (1958). The microstructure and colloidal stability of warm clouds. Tellus 10: 262-271, doi: 10.1111/j.2153-3490.1958.tb02012.x.

Storelvmo, T., Kristjánsson, J.E., Ghan, S.J., Kirkevåg, A., Seland, O. and Iversen, T. (2006). Predicting cloud droplet number concentration in Community Atmosphere Model (CAM)-Oslo. J. Geophys. Res. 111: D24208, doi: 10.1029/2005JD006300.

Teller, A. and Levin, Z. (2006). The effects of aerosols on 
precipitation and dimensions of subtropical clouds; a sensitivity study using a numerical cloud model. Atmos. Chem. Phys. 6: 67-80.

Tripathi, S.N., Dey, S., Chandel, A., Srivastava, S., Singh, R.P. and Holben, B.N. (2005). Comparison of MODIS and AERONET derived aerosol optical depth over the Ganga Basin, India. Ann. Geophys. 23: 1093-1101, doi: 10.5194/angeo-23-1093-2005.

Twomey, S. (1977). The influence of pollution on the shortwave albedo of clouds. J. Atmos. Sci. 34: 11491152, doi: 10.1175/1520-0469(1977)034<1149:TIOPO $\mathrm{T}>2.0 . \mathrm{CO} ; 2$.

Twomey, S.A., Piepgrass, M. and Wolfe, T.L. (1984). An assessment of the impact of pollution on global cloud albedo. Tellus B 36: 356-366.

Várnai, T. and Marshak, A. (2015). Effect of cloud fraction on near-cloud aerosol behavior in the MODIS atmospheric correction ocean color product. Remote Sens. 7: 5283-5299, doi: 10.3390/rs70505283.

Verma, S., Venkataraman, C. and Boucher, O. (2008). Origin of surface and columnar Indian Ocean Experiment (INDOEX) aerosols using source- and region-tagged emissions transport in a general circulation model. $J$. Geophys. Res. 113: D24211, doi: 10.1029/2007JD009538.

Wang, F., Guo, J., Wu, Y., Zhang, X., Deng, M., Li, X., Zhang, J. and Zhao, J. (2014). Satellite observed aerosol-induced variability in warm cloud properties under different meteorological conditions over eastern China. Atmos. Environ. 84: 122-132.

Warner, J. (1968). A reduction in rainfall associated with smoke from sugar-cane fires: An inadvertent weather modification? J. Appl. Meteorol. 7: 247-251, doi: 10.1175/
1520-0450(1968)007<0247:ARIRAW>2.0.CO;2.

Wentz, F.J. and Spencer, R.W. (1998). SSM/I rain retrievals within a unified all-weather ocean algorithm. J. Atmos. Sci. 55: 1613-1627, doi: 10.1175/1520-0469(1998)055 $<1613$ :SIRRWA $>2.0 . \mathrm{CO} ; 2$.

Xue, H. and Feingold, G. (2006). Large-eddy simulations of trade wind cumuli: Investigation of aerosol indirect effects. J. Atmos. Sci. 63: 1605-1622, doi: 10.1175/JAS 3706.1.

Xue, H., Feingold, G. and Stevens, B. (2008). Aerosol effects on clouds, precipitation, and the organization of shallow cumulus convection. J. Atmos. Sci. 65: 392406, doi: 10.1175/2007JAS2428.1.

Yin, Y., Levin, Z., Reisin, T.G. and Tzivion, S. (2000). The effects of giant cloud condensation nuclei on the development of precipitation in convective clouds-A numerical study. Atmos. Res. 53: 91-116, doi: 10.1016/ S0169-8095(99)00046-0.

Yuan, J., Hartmann, D.L. and Wood, R. (2008). Dynamic effects on the tropical cloud radiative forcing and radiation budget. J. Clim. 21: 2337-2351, doi: 10.1175/2007JCL I1857.1.

Zhang, L., Michelangeli, D.V. and Taylor, P.A. (2006). Influence of aerosol concentration on precipitation formation in low-level, warm stratiform clouds. J. Atmos. Sci. 37: 203-217, doi: 10.1016/j.jaerosci.2005.04.002.

Received for review, April 25, 2018

Revised, August 9, 2018 Accepted, February 26, 2019 